\title{
The Aplocnemus Stephens, 1830, of Greece (Coleoptera, Cleroidea, Dasytidae). A contribution to their knowledge
}

\author{
Gianfranco Liberti
}

\begin{abstract}
The first part of the paper includes an overview of genus Aplocnemus and a discussion of the related subgenera; as a result one of them is placed in synonymy: Holcopleura Schilsky, $1894=$ Aplocnemus (Aplocnemus) Stephens, 1830.

The second part deals with the 16 Aplocnemus species found to live in Greece. Out of these, 9 are fully discussed, with descriptions and drawings of dissected structures (median lobe, tegmen, last sternite). The remaining 7 have been already - and rather recently - considered and illustrated in previous papers: for them only new taxonomic and/or distributional information are herewith supplied.

One new taxon is described: Aplocnemus henrici sp. $\mathbf{n}$ from northern Greece and Bulgaria. 9 new synonymies, at species level, are proposed: A. macedonicus Pic, $1922=$ A. (Aplocnemus) basalis (Küster, 1849); A. pristocerus Kiesenwetter, $1859=$ A. (Aplocnemus) caelatus (Brullé, 1832); A. brevissimus Pic, $1908=$ A. (Aplocnemus) quercicola Mulsant \& Rey, 1968; A. kiesenwetteri Schilsky, $1897=$ A. (Aplocnemus) rufipes Miller, 1862; A. turcicus Schilsky, $1897=A$. (Aplocnemus) reitteri Schilsky, 1894; A. cribripennis Pic, $1921=$ A. $($ Aplocnemus $)$ serratus (Brullé, 1832); A. latior Pic, 1908, A. thessalicus Pic, 1908 and A. atricornis Pic, $1921=$ A . (Diplambe $)$ abietum Kiesenwetter, 1859 .
\end{abstract}

Key words: Balkan Peninsula, taxonomy, new species, synonymies, Bulgaria, Croatia, Montenegro, Turkey.

Riassunto - Aplocnemus Stephens, 1830, della Grecia (Coleotteri, Cleroidea, Dasytidae). Un contributo alla loro conoscenza.

La prima parte dell'articolo include una panoramica del genere Aplocnemus e una discussione sui relativi sottogeneri; come risultato, uno di essi è posto in sinonimia: Holcopleura Schilsky, $1894=$ Aplocnemus (Aplocnemus) Stephens, 1830.

La seconda parte del lavoro tratta delle 16 specie di Aplocnemus la cui presenza in Grecia ha potuto essere verificata. Di queste, 9 vengono pienamente discusse, con descrizioni e disegni di parti anatomiche (lobo mediano, tegmen, ultimo sternite). Le rimanenti 7 sono già state considerate e illustrate - piuttosto recentemente - in lavori precedenti: per essi vengono qui fornite solo ulteriori nuove informazioni tassonomiche e/o distributive.

Viene descritto un nuovo taxon: Aplocnemus henrici n. sp. dalla Grecia settentrionale e dalla Bulgaria. Si propongono 9 nuove sinonimie a livello di specie: A. macedonicus Pic, $1922=$ A. (Aplocnemus) basalis (Küster, 1849); A. pristocerus Kiesenwetter, $1859=$ A (Aploc-

Via Cascina Girola 81, 21040 Uboldo (VA), Italia.

E-mail: gianfrancoliberti@alice.it

\section{(C) 2018 Gianfranco Liberti}

Received: 25 January 2018

Accepted for publication: 5 September 2018

Online publication: 29 November 2018 nemus) caelatus (Brullé, 1832); A. brevissimus Pic, $1908=$ A. (Aplocnemus) quercicola Mulsant \& Rey, 1968; A. kiesenwetteri Schilsky, $1897=$ A. (Aplocnemus) rufipes Miller, 1862; A. turcicus Schilsky, $1897=$ A. (Aplocnemus) reitteri Schilsky, 1894; A. cribripennis Pic, $1921=$ A. (Aplocnemus) serratus (Brullé, 1832); A. latior Pic, 1908, A. thessalicus Pic, 1908 e A. atricornis Pic, $1921=$ A. (Diplambe $)$ abietum Kiesenwetter, 1859.

Parole chiave: Penisola balcanica, tassonomia, nuove specie, sinonimie, Bulgaria, Croazia, Montenegro, Turchia.

\section{INTRODUCTION}

Following Mayor (2007) genus Aplocnemus belongs to family Dasytidae, subfamily Rhadalinae, tribe Aplocnemini. Family rank for Rhadalinae has been recently suggested by Bocakova et al. (2011) based on a molecular phylogenetic analysis of the whole Melyridae group (Dasytidae, Malachiidae, Mauroniscidae, Melyridae, Prionoceridae, Rhadalidae) and, as a matter of facts, Rhadalinae appear rather different from the other Dasytidae. Whatever it could be, the Rhadalinae rank is not really relevant to the purpose of this paper.

Genus Aplocnemus is Palaearctic and its known distribution ranges from the Atlantic coasts of France to the Altai Mountains Range in central Asia, at latitudes approximately included between $30^{\circ}$ and $55^{\circ}$ (see also Mayor, 2007). It is a large genus: in his Catalog, Mayor (2007) lists nearly 150 valid taxa. Out of them, 16 species are known for Greece and are here included.

In recent years Aplocnemus has been the subject of several papers (Majer, 1982, 1985; Peacock, 1987; Liberti, 1995; Liberti \& Zinetti, 2009; Constantin, 2005, 2007) mainly dealing with species of central Europe and western Mediterranean area (France, Spain and Italy). On the other hand, the knowledge of Aplocnemus species living in north Africa, eastern Mediterranean Countries (the Balkan Peninsula, Turkey, Middle East), eastern Europe and other Asiatic countries still is poor and mainly based on the Kiesenwetter $(1859,1863)$ and Schilsky $(1894 a, 1897)$ papers, more than one century old. The present work aims at partially filling this gap, reviewing the Aplocnemus species of southern Balkans.

Aplocnemus are usually good flyers and can be found by beating trees and shrubs or sweeping grass. Certain species appear to be rare or very rare although trap (flight 
interception, Malaise etc.) collection may, at times, suggest they might be more frequent than expected. Their biology is rather unknown although, for several species, there is evidence of saproxylic behaviour (Russo, 1938; Prota, 1966); information and bibliography relating to Aplocnemus biology and larval anatomy can be found in Constantin \& Klausnitzer (1996). Adults usually appear in spring or early summer, depending on altitude, but certain species may disclose in late autumn or in winter (Russo, 1938; Liberti, 2009).

This paper is based both on materials personally collected by the writer in several entomological trips to Greece $(1997,1998,2001,2005,2006,2007)$, Croatia and Montenegro (2002, 2003, 2004, 2008) and Turkey (2010, 2011) and on materials kept in several private and public collections (see list of depositories). The types of many species, although not all, have been retrieved and studied as below detailed.

\section{MATERIALS AND METHODS}

\section{Territory}

Included in this paper are only those species for which a clear evidence of their presence in Greece has been found. For them, collection localities in other Balkanic countries, Romania and Turkey are also reported, if any.

The Countries abbreviations used in the text are listed below, under "Lists and Abbreviations".

All Greek localities, as reported under "Materials studied", are grouped by administrative provinces (nomos). To ease understanding their location, a sketch of the administrative structure of Greece, taken from the below mentioned "Euro Atlas", is supplied in Fig. 1.

\section{Materials, dissections and drawings}

The materials actually studied, well in excess of one thousand specimens, are in the writer's collection or have been borrowed from several collections, either of public access (Museums) or private, listed under "Lists and Abbreviations".

All dissections have been carried out working (in water) under a stereomicroscope (at variable magnifications, usually from $15 \mathrm{x}$ to $30 \mathrm{x}$ ) with the thinnest micropins found on the market $(0.1 \mathrm{~mm})$, suitably hooked at the sharp extremity and fitted with a wooden handle at the other. The insects have been softened by immersion in a solution of ethyl-alcohol in water (5-10\%) for many hours (not less than 10-12) and the abdomen carefully detached. Afterwards the abdomen only has been further softened by $1-2$ minutes boiling in dilute potassium hydroxyde solution $(1-2 \%)$, its dorsal integument opened, the whole content (inclusive of both last sternite and tergite) draw out and boiled again 1-2 minutes in the same $\mathrm{KOH}$ solution (the empty abdomen has been glued on the insect cardboard). Eventually the sclerotized components - namely median lobe [with its internal structure named dorsal lever (see below under "Meaning of some terms used in descriptions")], tegmen, spicular fork, pygidium and last sternite - have been separated from each other and mounted in
DMHF [using a DiMethyl-Hydantoine-Formaldehyde solution made up with $60 \%$ weight DMHF plus $40 \%$ weight of a water based solvent $-40 \%$ volume water $+60 \%$ volume propylenglycol-monomethylether - whose manufacturing procedure has been described, in details, elsewhere (Liberti, 2005)] on a small transparent cellulose acetate label pinned under the insect cardboard.

This rather cumbersome procedure is necessary to keep the insect undamaged and to allow the dorsal lever (of median lobe) to remain well visible after mounting.

All drawings have been made with the aid of a calibrated grid mounted on the ocular lens of a stereomicroscope, at variable magnifications.

Photographs have been taken by means of a camera placed on the video tube of the same stereomicroscope and the multiple focus frames combined with Helicon Focus 6 software.

\section{Note on explicit indication of subgenera}

Throughout the text subgenera have been often declared, as suggested by the code (ICZN 1999: art. 6.1), by interpolation in parentheses between generic and specific names, at times abbreviated. However, in captions, subgenera have been omitted when the species belongs to Aplocnemus subgenus Aplocnemus. That does not cause any loss of clarity and - taking into account that the great majority of the Greek species belong to subgenus Aplocnemus - results in easier reading and shorter captions.

\section{Notes to "Systematics"}

Meaning of terms used througout the paper can be found in Cooter (2006: 413, Glossary). Information on, and meaning of, a few more terms are here below reported. Abbreviations used in descriptions are listed below.

\section{Meaning of some terms used in descriptions}

Aedeagus: the assembly of tegmen and median lobe (with dorsal lever) (Figs. 17, 18, 20).

Dimensions: when dimensions are supplied as simple intervals (for example: $\mathrm{TL}=5.8-6.5 \mathrm{~mm}$ ) it means that the reported numbers are the maximum and minimun values actually measured on the specimens available for study. When dimensions are supplied as average plus a confidence interval (for example TL $=6.12 \pm 0.26 \mathrm{~mm}$ ), both have been evaluated on 5 measures (unless otherwise stated) and, the latter, by t-test at $95 \%$ probability level, selecting the specimens from different localities (whenever possible).

Balanced: length and width approx. equal.

Dorsal lever: a term introduced by Majer (1982: 422) to designate the sclerotized process of the internal sac (of median lobe) approximately shaped as a hook (and present in all Aplocnemus species) wich bears important diagnostic characters, at least in subgenus Aplocnemus. This same process was named "dorsal appendage" or "dorsal sclerite" by Peacock (1987: 130, Fig. 7). 


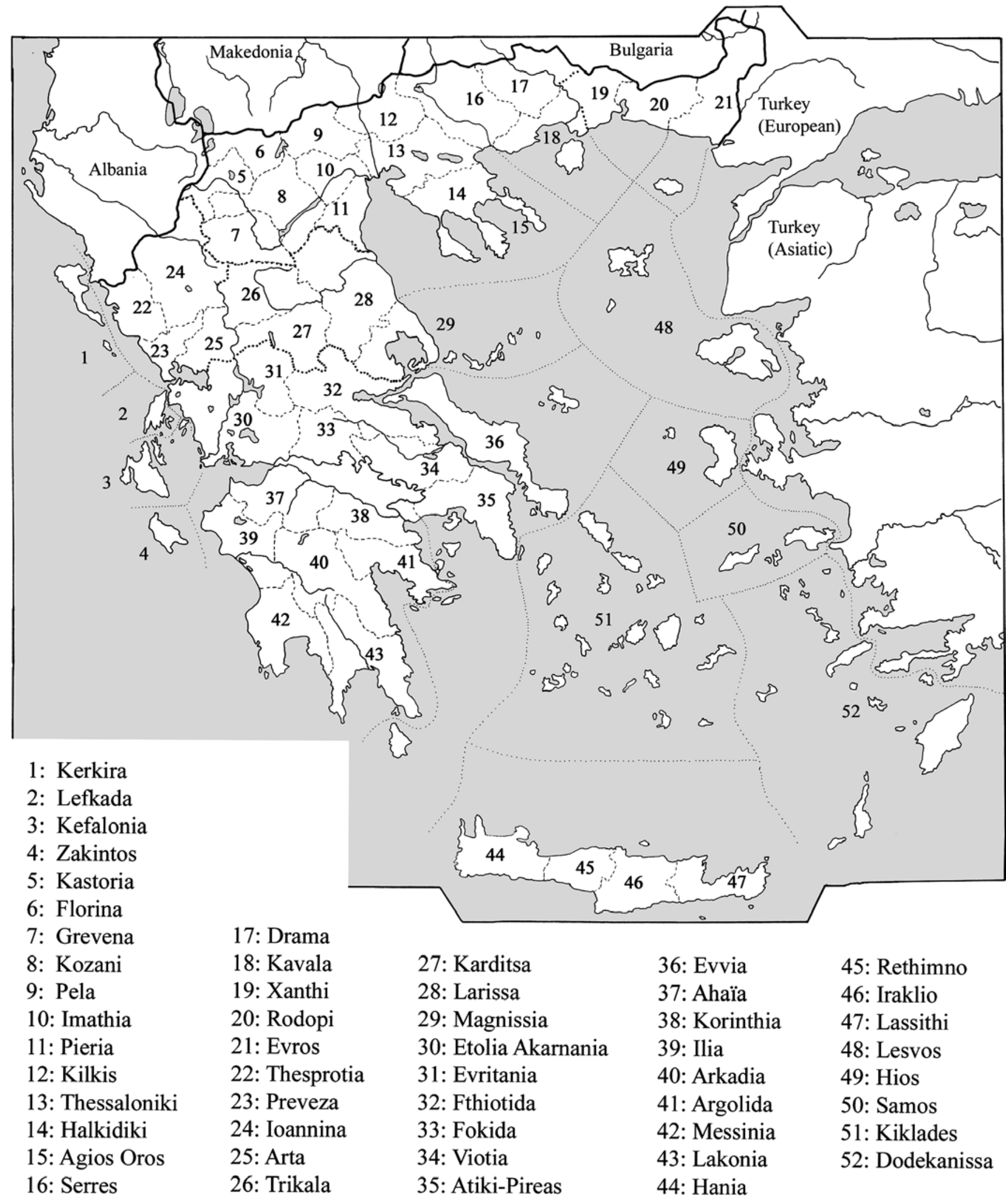


Elongate: longer than wide.

Parameres: the couple of sclerotized "lateral processes" of tegmen, joined to each other both basally and apically (Fig. 46).

Phallobase: the basal part of tegmen, more or less loosely connected (by a membrane) with the median lobe base (Figs. 22, 27, 30, see also Fig. 20).

Spicular fork: the bilobate process connecting last sternite and tergite with aedeagus and hind-intestine (Figs. $15,16,45,49)$.

Transverse: wider than long.

\section{Note on median lobe drawings}

The terms "lateral view" and "ventral view", used to qualify median lobe drawings, may seem incorrect and must be explained. Indeed, on dissection, the Aplocnemus (Aplocnemus) aedeagi appear often placed as shown in Fig. 16 so that, instead of "lateral view", use of "sternal view" would seem better. But, in fresh (recently dead) specimens the median lobe appears $90^{\circ}$ rotated opposite to the reader, with convexity and "dorsal lever" on dorsal side (namely concavity on sternal side).

\section{Notes to "Discussion of the species"}

The list of bibliographical references reported for each species is largely incomplete before the year 1937, publication date of the Pic's "Junk Catalog" (Pic, 1937); please refer to it for a complete record.

A detailed description, with drawings, is here provided only for those species that are not included in Liberti (1995) and/or in Constantin (2007).

Under "Materials studied" records are compacted and reported as "locality name" followed by collector's name, collecting year (collection day and month have been felt unnecessary because, for all the species here discussed, adults appear in spring or early summer depending on altitude) and depository in brakets. Lacking data are replaced by question marks. Greek and Turkish locality names are grouped by provinces and listed in alphabetical order. Other Countries localities are simply listed in alphabetical order (unless differently stated). To avoid unnecessary repetitions, for some widespread species [those already included in Liberti (1995) and/ or in Constantin (2007)] only records from the Balkan Peninsula Countries, Romania and Turkey are reported; for these same species further records relating to central and western Europe may also be found in Majer (1982) and Liberti \& Zinetti (2009).

For each species only reliable collection localities are reported. Materials have been usually studied by the writer, however also data supplied by R. Constantin (private communications) have been included (these marked by an asterix: see abbreviations). Localities names appear either in the relevant "Euro Atlas" published by RV Verlag (Greece 1:300.000; Turkey 1:800.000; Dalmatia, Istria 1:100.000; Croatia, Slovenia, Bosnia I Hercegovina 1:300.000) or in the "Osteuropa Compact" Atlas 1:700.000 published by Freytag \& Berndt.

\section{LISTS AND ABBREVIATIONS}

Depositories of materials studied

$\mathrm{BMNH}=$ British Museum, Natural History, London, England

CAn $=$ Collection Fernando Angelini, kept at the Natural History Museum, Florence, Zoological Department

"La Specola", Italy

$\mathrm{CBu}=$ Collection Hervé Brustel, Toulouse, France

$\mathrm{CCo}=$ Collection Robert Constantin, Saint Lô (Manche), France

$\mathrm{CEg}=$ Collection Manfred Egger, Wattens (Tyrol), Austria

$\mathrm{CFr}=$ Collection Mario E. Franciscolo $(\dagger)$, now at MSNG

$\mathrm{CGz}=$ Collection Tomasz Gazurek, Warsaw, Poland

$\mathrm{CKn}=$ Collection Ondrej Konviçka, Zlin, Czech Republic

CKo $=$ Collection Andreas Kopetz, Amt Wachsenburg, Germany

$\mathrm{CLi}=$ Collection Gianfranco Liberti, Uboldo (Varese), Italy

$\mathrm{CMg}=$ Collection Enrico Migliaccio, Roma, Italy

$\mathrm{CPl}=$ Collection Isidor Plonski, Wien, Austria

$\mathrm{CPn}=$ Collection Philippe Ponel, Pourcieux (Var), France

$\mathrm{CRe}=$ Collection Karel Rébl, Praha, Czech Republik

$\mathrm{CSl}=$ Collection Lucio Saltini, Carpi (Modena), Italy

$\mathrm{CTd}=$ Collection Michele Tedeschi, Milan, Italy

$\mathrm{CWh}=$ Collection Paul Whitehead, Pershore, United Kingdom

CWo $=$ Collection Thomas Wolsch, Berlin, Germany

$\mathrm{CZi}=$ Collection Wolfgang Ziegler, Hamburg, Germany

$\mathrm{MNH}=$ Hungarian Natural History Museum, Budapest, Hungary

MNHNP = Museum National d'Histoire Naturelle, Paris, France

MRSN $=$ Museo Regionale di Scienze Naturali, Torino, Italy

MSNG = Museo Civico di Storia Naturale "Giacomo Doria", Genova, Italy

MSNM = Museo di Storia Naturale, Milano, Italy

MZF = Finnish Museum of Natural History, Helsinki, Finland

NHMB $=$ Naturhistorisches Museum, Basel, Switzerland

NHMW = Naturhistorisches Museum, Wien, Austria

SMNS = Museum für Naturkunde, Stuttgart, Germany

$\mathrm{ZMB}=$ Museum für Naturkunde, Humboldt Universität,

Berlin, Germany

ZMLU $=$ Museum of Zoology, Lund University, Sweden

\section{Countries abbreviations}

$\mathrm{AL}=$ Albania

$\mathrm{BG}=$ Bulgaria

$\mathrm{CH}=$ Switzerland

$\mathrm{HR}=$ Croatia

$\mathrm{CY}=$ Cyprus

$\mathrm{F}=$ France

$\mathrm{GR}=$ Greece

$\mathrm{H}=$ Hungary 
$\mathrm{I}=$ Italy

$\mathrm{MK}=$ Makedonia

$\mathrm{MNE}=$ Montenegro

$\mathrm{RO}=$ Romania

SLO = Slovenia

$\mathrm{TK}=$ European Turkey

$\mathrm{TR}=$ Asiatic Turkey

\section{Other abbreviations}

approx. = approximately

coll. $=$ collection

$\mathrm{EL}=$ elytral length

$\mathrm{EW}=$ elytral width

hw $=$ handwritten

hwA = handwritten by the species Author

Is. = Island

loc. typ. = typical locality

max. = maximum

Mts. $=$ Mountains

nr. $=$ number $(\mathrm{s})$

Pen. $=$ Peninsula

$\mathrm{PL}=$ pronotum length

pr. $=$ printed

prov. $=$ province

prr. $=$ printed on red paper (or cardboard)

$\mathrm{PW}=$ pronotum width

$\mathrm{TL}=$ total length (measured from labium to elytral apex)

up. = unpublished (applies to certain typical specimens bearing type designation labels not supported by subsequent publication)

? = lacking entry in locality records (only under "Materials studied")

/ (within the text of a label) $=$ end of a line

${ }^{\circ}=$ locality already reported in Liberti (1995)

$\circ$ = locality already reported in Liberti \& Zinetti (2009)

$*=\mathrm{R}$. Constantin personal communication (only when found under "Materials studied")

(T) = Topotypes

(F) = females only (determinations may not be $100 \%$ sure)

\section{DISCUSSION OF APLOCNEMUS SUBGENERA}

Genus Aplocnemus was established by Stephens (1830) for Crioceris impressa Marsham, 1802 and the use of this name, instead of Elicopis Stephens, 1829 has been recently explained (Peacock, 1987; Liberti, 1995). The spelling Haplocnemus is an unjustified emendation introduced by Agassiz (1846: 172).

Aplocnemus was split into four subgenera by Schilsky (1894b: 234):

Aplocnemus (Aplocnemus); type species Crioceris impressa Marsham, 1802, by original designation (see also Peacock, 1987: 152).

Aplocnemus (Diplambe); type species A. (Diplambe) montivagus Rosenhauer, 1856, designated by Peacock (1987: 152).

Aplocnemus (Holcopleura); type species A. (Holcopleura) reitteri Schilsky, 1894, by monotypy (Schilsky, 1894b: 234).
Aplocnemus (Ischnopalpus); type species A. (Ischnopalpus) subcostatus Schilsky, 1894, by subsequent designation (Schilsky, 1894a: 62).

Shortly afterwards Pic (1896: 47) added a fifth subgenus:

Aplocnemus (Pseudaphictus); type species A. tournieri Pic, 1896 by monotypy (see also Peacock, 1987: 152).

These five subgenera have been accepted by Schilsky (1897), Pic (1937) and Peacock (1987). The paper of Peacock (1987) is a nice revision of the whole subfamily Rhadalinae with excellent illustrations, however she does not discuss the Aplocnemus subgenera and lists all the species together in alphabetical order.

A couple of decades later Constantin (2005: 219) synonymized Aplocnemus (Pseudaphictus) with Aplocnemus (Aplocnemus), a proposal fully shared by the writer because the subgenus was created only based on elytral shape - namely humeral callous reduced to absent, elytra rounded and widened in the middle - which is not structural but simply linked to apterism (or to reduced wings).

Aplocnemus (Diplambe) has been defined (Schilsky, 1894b: 234) on the ground of the lateral elytral border appearing double [due to the presence of a "sublateral carina in basal half, forming a double elytral edge" (Peacock, 1987: 136)]: a well evident character shared with Rhadalus LeConte, 1852 (Peacock, 1987: Fig. 16). Furthermore in A. (Diplambe) phallobase and parameres are not fused together and appear connected by membranous tissues (Fig. 50; see also Majer, 1987: Fig. 212), a character shared by genus Trichoceble Thomson, 1859 (Liberti, 2012: Figs. 8, 28, 39, 43).

Aplocnemus (Ischnopalpus) has been defined mainly on the ground of maxillary palps last article which is spindle shaped instead of being securiform (Peacock, 1987: Figs. 31, 32). Schilsky (1897: 34BB) also suggests a couple of further characters: dorsal surface black and strongly punctuate and longer epipleura, but these are not always fully valid [as for example A. (Ischnopalpus) gracilicornis Schilsky, 1897]. However the validity of Ischnopalpus, possibly up to generic level, is also supported by the aedeagus shape, characterized by an overdeveloped tegmen enveloping a smaller median lobe (Figs. 15, 17, 18; see also Majer, 1987: Fig. 205) while in A. (Aplocnemus) the tegmen is placed astride a well developed median lobe (Figs. 16, 20). Also note the Ischnopalpus spicular fork apically strongly bent dorsally, against the Aplocnemus one which is moderately bent.

On the other hand A. (Holcopleura), established by Schilsky (1894b: 234, 1897: 34BBB) for $A$. reitteri, was based on just one character: the propleura ("Pleuren des Halsschildes") fitted with a transverse impression ("querfurche"); namely the front legs coxal grooves extend, although with reduced depth, nearly up to the lateral sides. But this character is often unclear, difficult to appreciate and can be (more or less) detected only in A. reitteri. In Greece three more species resembling $A$. reitteri can be found: A. caelatus, A. cribrarius and A. henrici. These four species show evident similarities and compose a homogeneous group: in spite of that the writer was not able to find any definite, clear cut differential character common only to these species, to support the Holcopleura 
subgenus validity (the Schilsky's "querfurche" appears, to the writer, inadequate; see also the discussion below). For this reason, the synonymy with $A$. (Aplocnemus) is here proposed:

Aplocnemus subgenus Holcopleura Schilsky, $1894=$ Aplocnemus subgenus Aplocnemus Stephens, 1830 syn. n.

Aplocnemus (Aplocnemus) are characterized (Schilsky, 1897: 34BB) by variable, more or less securiform, truncated last article of maxillary palpi (Peacock, 1987: Fig. 31) and simple elytral lateral border.

Considering the maxillary palpi last article, in its present meaning subgenus Aplocnemus includes species with apical edge longer than internal edge (largely securiform) as well as others where apical edge is as long as (or even shorter than) internal edge (less evidently hatchet shaped); a number of species also have (males) with a round, finely pubescent impression on first and (often) second visible sternites (Constantin, 2005: Fig. 6). These two characters are (to some extent) related: species with the round impression on sternites also show clearly securiform last palpi article; on the other hand species with sim- ple sternites also have last palpi article "less securiform" (namely longer with shorter apical edge). The latter case include our four species: A. caelatus, A. cribriarius, $A$. henrici and $A$. reitteri, together with many others (as, for example, A. cylindricus Kiesenwetter, 1863, A. angelinii, $A$. jejunus and others). It might be that, in the future, subgenus Aplocnemus could be split taking these characters into account (in the writer's opinion these criteria are, anyway, well outside the definition of the Schilsky's subgenus Holcopleura).

As a conclusion, three out of the four Schilsky's subgenera, namely $A$. (Aplocnemus), A. (Diplambe) and $A$. (Ischnopalpus) show good differential external characters as well as important aedeagical differences: they are deemed to be valid and are here accepted. Whether they should be considered subgenera, or should be raised to good genera, is beyond the scope of the present paper.

Table 1 summarizes the main differences between the three valid subgenera: A. (Aplocnemus), A. (Diplambe) and $A$. (Ischnopalpus) (however please note that no Ischnopalpus lives in the territory here considered).

Tab. 1 - Main differential characters between Aplocnemus subgenera.

$*=A$. (Ischnopalpus) subcostatus Schilsky, 1894, type species of this subgenus, has been here chosen as representative. It is very common in Morocco, from the sea level to over $2000 \mathrm{~m}$ elevation (original, unpublished data). But taxonomy is uncertain [it might be a possible synonym of $A$. (Ischnopalpus) morio (Schönerr, 1817)] and this name may turn out, in the future, as incorrect.

\begin{tabular}{|c|c|c|c|}
\hline & subg. Aplocnemus & subg. Diplambe & subg. Ischnopalpus* \\
\hline Median lobe shape & $\begin{array}{l}\text { Tubular, approx. same } \\
\text { thickness in lateral and } \\
\text { ventral views; in lateral } \\
\text { view more or less, but } \\
\text { always clearly, arched } \\
\text { (namely bent sternally at } \\
\text { base and/or at apex: see, } \\
\text { for example, Fig. 20). }\end{array}$ & $\begin{array}{l}\text { Tubular, in lateral view } \\
\text { thinner, flattened, either } \\
\text { bent (basally and/or } \\
\text { apically) or more or less } \\
\text { straight; in ventral view } \\
\text { wider, elongate, sub- } \\
\text { elliptical (Figs. } 47,48 \text { ). }\end{array}$ & $\begin{array}{l}\text { Dorsally open, in lateral } \\
\text { view rather thin, straight } \\
\text { or slightly convex on } \\
\text { sternal side; in ventral } \\
\text { view elongate, more or } \\
\text { less sub-elliptical (Figs. } \\
15,17,18) \text {. }\end{array}$ \\
\hline Tegmen & $\begin{array}{l}\text { Flat, obliquely encircling } \\
\text { median lobe (Figs. 16, } \\
\text { 20). Phallobase and } \\
\text { parameres fused together } \\
\text { (Figs. 22, 27, 30). } \\
\text { Sclerotized border of } \\
\text { parameres narrow (Fig. } \\
46 \text { ). }\end{array}$ & $\begin{array}{l}\text { Flat, obliquely encircling } \\
\text { median lobe (as in Fig. } \\
\text { 16). Phallobase and } \\
\text { parameres not fused but } \\
\text { connected by a membrane } \\
\text { (Fig. 50). Sclerotized part } \\
\text { of parameres rather wide } \\
\text { (Fig. 50). }\end{array}$ & $\begin{array}{l}\text { Approx. tubular (open } \\
\text { tergally), fully enveloping } \\
\text { the median lobe (Figs. } \\
17,18 \text { ). Phallobase and } \\
\text { parameres fused together } \\
\text { (Fig. 17). Nearly entirely } \\
\text { sclerotized (Figs. 17, 18). }\end{array}$ \\
\hline $\begin{array}{l}\text { Central process of last } \\
\text { sternite }\end{array}$ & $\begin{array}{l}\text { More or less evident: very } \\
\text { short to well developed. }\end{array}$ & $\begin{array}{l}\text { Short or very short (Fig. } \\
51 \text { ). }\end{array}$ & $\begin{array}{l}\text { Rudimentary to very } \\
\text { short (Fig. 15). }\end{array}$ \\
\hline Elytral lateral side & Simple & $\begin{array}{l}\text { Appearing double at least } \\
\text { in basal half }\end{array}$ & Simple \\
\hline Palpi & $\begin{array}{l}\text { Securiform to sub- } \\
\text { elliptical, apically widely } \\
\text { truncated. }\end{array}$ & $\begin{array}{l}\text { Sub-elliptical, apically } \\
\text { evidently truncated. }\end{array}$ & $\begin{array}{l}\text { Fusiform, apically very } \\
\text { shortly truncated. }\end{array}$ \\
\hline
\end{tabular}


THE APLOCNEMUS SPECIES OF GREECE

\section{Checklist}

\begin{tabular}{|c|c|c|}
\hline Species & Distribution & Typical locality \\
\hline $\begin{array}{l}\text { Aplocnemus (Diplambe) abietum Kiesenwetter, } 1859 \\
\quad=\text { A. thessalicus } \text { Pic, } 1908 \text { (syn. n.) } \\
\quad=\text { A. atricornis } \text { Pic, } 1921 \text { (syn. n.) } \\
\quad=\text { A. latior Pic, } 1908 \text { (syn. n.) }\end{array}$ & RO, MK, BG, GR, TR (?) & $\begin{array}{l}\text { Oros Parnitha near Athens } \\
\text { (GR) }\end{array}$ \\
\hline Aplocnemus (A.) angelinii Liberti, 1995 & I, AL, GR (Corfù) & Policoro (Basilicata, I) \\
\hline $\begin{array}{l}\text { Aplocnemus }(\text { A.) basalis (Küster, 1849) } \\
\quad=\text { A. macedonicus Pic, } 1922 \text { (syn. n.) } \\
\quad=\text { A. basalis var. distinctipes Pic, } 1908\end{array}$ & HR, MNE, GR, TR & Trogir (HR) \\
\hline $\begin{array}{l}\text { Aplocnemus }(\text { A.) caelatus (Brullé, 1832) } \\
\quad=\text { A. pristocerus Kiesenwetter, } 1859 \text { (syn. n.) }\end{array}$ & GR & Peloponnesus \\
\hline Aplocnemus (A.) corcyricus Miller, 1866 & I, GR & Kerkyra Island (GR) \\
\hline Aplocnemus (A.) cribrarius (Brullé, 1832) & GR & Peloponnesus \\
\hline Aplocnemus (A.) henrici sp. n. & BG, GR & $\begin{array}{l}\text { Mount Vitoscia near Sofia } \\
\text { (BG) }\end{array}$ \\
\hline Aplocmenus (A.) integer Baudi, 1874 & $\mathrm{~F}, \mathrm{I}, \mathrm{CH}, \mathrm{H}, \mathrm{RO}, \mathrm{BG}, \mathrm{GR}, \mathrm{TR}$ & Pavia (I) \\
\hline Aplocnemus (A.) jejunus Kiesenwetter, 1863 & F, I, SLO, HR, BG, GR, TR & southern France \\
\hline Aplocnemus (A.) marginatus Rottenberg, 1871 & I (Sicily), GR & Catania (Sicily, I) \\
\hline Aplocnemus (A.) nigricornis (Fabricius, 1792) & All Europe, TR & Sweden \\
\hline $\begin{array}{l}\text { Aplocnemus }(\text { A.) pertusus Kiesenwetter, } 1859 \\
\quad=(?) \text { A. libanicus Pic, } 1901\end{array}$ & GR, TR, CY & Napflio (GR) \\
\hline $\begin{array}{l}\text { Aplocnemus (A.) quercicola Mulsant \& Rey, } 1869 \\
\quad=\text { A. brevissimus Pic, } 1908 \text { (syn. n.) }\end{array}$ & F, I, GR & Beaujolais et Lyon area (F) \\
\hline $\begin{array}{l}\text { Aplocnemus }(\text { A.) reitteri Schilsky, } 1894 \\
\quad=\text { A. turcicus Schilsky, } 1897 \text { (syn. n.) }\end{array}$ & GR, BG, TK, TR & Izmir (TR) \\
\hline $\begin{array}{l}\text { Aplocnemus }(\text { A.) rufipes Miller, } 1862 \\
\quad=A \text {. kiesenwetteri Schilsky, } 1897 \text { (syn. n.) } \\
\quad=A . \text { rufipes var. taygetana Pic, } 1908 \\
\quad=A . \text { rufipes var. semicaeruleus } \text { Pic, } 1922\end{array}$ & GR, TR & $\begin{array}{l}\text { Enos Oros on Kefallonia Island } \\
\text { (GR) }\end{array}$ \\
\hline $\begin{array}{l}\text { Aplocnemus (A.) serratus (Brullé, 1832) } \\
\quad=\text { A. cribripennis Pic, } 1921 \text { (syn. n.) }\end{array}$ & $\mathrm{HR}, \mathrm{GR}$ & Peloponnesus \\
\hline
\end{tabular}

For all the above listed taxa, reliable evidence of their presence in Greece has been found. But at least three further species, present in the northern part of the Balkans, might be found in this Country:

Aplocnemus (A.) chalconatus (Germar, 1817): similar to rufipes for general appearance and colour, known of Slovenia, Croatia (Istria, Dalmatia) and Montenegro (Majer, 1982; Liberti, 1995).

Aplocnemus (A.) pulverulentus (Kuster, 1849): belonging to the reitteri group, known of Slovenia, Croatia and Montenegro (Liberti, 1995).

Aplocnemus (A.) serbicus Kiesenwetter, 1863: similar to rufipes but darker, known of Serbia, se- veral central European localities and the Russian southern Territories. A likely synonym of Aplocnemus (A.) virens Suffrian, 1843 from western Europe, its systematic position will be discussed in a future paper.

Their descriptions and drawings can be found in Majer (1982) and in Liberti (1995).

Determination key (males only) for the Greek species

This key includes 15 species of Aplocnemus (A.) plus one of $A$. (Diplambe). No A. (Ischnopalpus) is known from Greece. 
The key uses, among others, male antennal characters: for this reason it is only applicable to males. Males can be recognized, from females, mostly for stronger antennae and, often, for elytral apical half parallel or only slightly widened; in the "reitteri group" the elytral apex is shortly and slightly flattened compared to females (namely less regularly rounded off).

1 Elytral lateral border appearing double (at least in basal half) due to the presence of an elytral lateral carina close to the epipleuron (subgen. Diplambe). $\mathrm{TL}=$ 4.5-5.0 $\mathrm{mm}$. A common species all over the southern part of the Balkan peninsula abietum

- Elytral lateral border simple (subgen. Aplocnemus ) ..................................................

2 Dorsal appearance variable: brown, greenish-grey, bluish or blackish; rather bright; moderately rough (Figs. 4-5). Pronotum and elytra roughness different; pronotum punctures from light to deep and strong, rather sparse, distance between punctures larger than their diameter, surface between punctures smooth and bright; elytral surface variably punctured or rugged. Antennae feebly serrate (nearly moniliate, Fig. 6), serrate (Fig. 7) or pectinate in males (Figs. 8-10) and serrate (from feebly to strongly) in females. Last palpi article securiform (hatchet shaped), truncated (apical side longer than, or equal to, inner side) ................... 3

- Dorsal appearance deep black, dull, very rough (Fig. 3 ), at most with green reflections. Both pronotum and elytra very rough; pronotum punctures deep and strong, very dense, distance between punctures smaller than their diameter, surface between punctures more or less alutaceous or dull; elytral surface rough, with punctures at times coalescing into each other. Antennae serrate (Figs. 11-14), only slightly more evidently in males than in females. Last palpi article sub-elliptical, truncated (apical side slightly shorter than inner side) 13

(Couplets 13 to 16 include five species: angelinii, caelatus, cribrarius, henrici and reitteri. A. angelinii is well characterised by its approximately cylindrical shape and brighter appearance and A. caelatus shows green reflections. The other 3 are really similar to each other and are difficult to recognize on external characters only. In all cases sexual differences are reduced: males differ only slightly from females for stronger antennae and elytral very apex feebly flattened).

$3 \hat{\delta}$ antennal articles 4 and 5 more or less triangular, narrower than 6-10; antennae strongly serrate or pectinate, with at least articles 6 and/or 7 either concave, S-shaped or approximately straight at inner side (Figs. 7-10)

- O antennal articles 4-10 similar to each other; antennae moderately or feebly serrate (to moniliate), article 6 and 7 convex at inner side (Fig. 6) ....

4 Pronotum transverse; feebly convex; approximately rectangular; lateral sides only feebly rounded: pronotum width in the middle slightly exceeding anterior and posterior sides; not (or very feebly) crenulated on lateral sides. Colour dark grey-green, elytral pubescence - at least in part - whitish gray. $\delta$ anten- nae pectinate: articles 6-7 longer than wide, concave on inner side (Fig. 10). TL $=5.5-6.0 \mathrm{~mm}$. A rare species spread in southern France, in Italy and probably all over the Balkans (possible presence in Turkey) jejunus - Pronotum more or less transverse, evidently convex, lateral sides more or less rounded (namely anterior and posterior sides shorter, max. width in the middle), lateral sides smooth or finely crenulated. Colour metallic blue, brown, dark greenish brown, bluishblack or blackish. Elytral pubescence blackish to pale brown, often with pale grey setae near lateral border. $\delta$ antennae serrate to pectinate with articles 6-7 either straight or S-shaped on inner side ............................ 5

5 Dorsal integuments blackish (often with greenish or bluish reflections) or metallic blue. Dorsal pubescence blackish. Legs black. First two visible sternites simple 6

- Dorsal integuments dark-brown to greenish-brown. Dorsal pubescence often with pale setae close to elytral border (except in basalis where dorsal setae are black). Legs usually yellow at least in part. At least first visible sternite with a pubescent round impression in the middle (except in basalis where first and second visible sternites are simple) .................................... 8

6 Antennae serrate with internal border of articles 6-9 nearly straight. Antennae often with articles 1 to 4 more or less spotted yellow. Size smaller. TL $=4.0-5.0$. Known from Croatia and Greece .................. serratus

- Antennae strongly serrate to pectinate with internal border of articles 6-9 clearly S-shaped. Antennae entirely black. Size larger $(\mathrm{TL}=4.7-7.0 \mathrm{~mm}) \ldots \ldots \ldots . .7$

7 Dorsal colour metallic blue. Antennae longer: article 3 triangular elongate, articles 6-9 approximately balanced. TL $=5.0-7.0 \mathrm{~mm}$. Central Europe, peninsular Italy, Balkans; (possible presence in Turkey)

integer

- Dorsal colour blackish with greenish reflections. Antennae shorter: article 3 triangular balanced, articles 6-9 transverse. $\mathrm{TL}=4.7-6.3 \mathrm{~mm}$. Known of Kerkyra island in Greece, southern Italy and Sicily

corcyricus

8 Elytral pubescence entirely black. Dorsal surface dark brown. First two visible sternites simple. Size smaller. $\mathrm{TL}=4.2-5.0 \mathrm{~mm}$. Croatia, Montenegro, Greece, Turkey ....................................................... basalis

- Elytral pubescence at least in part (close to elytral border) paler, withish gray. Dorsal surface either brown or dark greenish. At least first sternite with a pubescent round impression in the middle. Size larger $(\mathrm{TL}=4.8-5.9 \mathrm{~mm})$.............................................. 9

9 Dorsal punctuation rather light, colour greenish. First two visible sternites with a round, pubescent impression in the middle. TL $=4.8-5.9 \mathrm{~mm}$. Greece, Turkey ................................................... rufipes

- Dorsal punctuation strong, colour brown. First visible sternite only with a round, pubescent impression in the middle. TL $=4.8-5.5 \mathrm{~mm}$. Greece, Turkey, Cyprus ...... pertusus

10 Entirely black, legs and antennae included. Body shape elongate, approx. cylindrical with head only 
slightly narrower than pronotum (in its max. width). Size larger. $\mathrm{TL}=6.8-7.5 \mathrm{~mm}$. Southern Italy, Albania, Kerkyra island in Greece .... angelinii

- At least tibiae yellowish or reddish. Body shape suboval with head clearly narrower than pronotum (in its max. width). Size smaller (TL $<5 \mathrm{~mm}$ ) 11

11 Pronotum very convex, not bordered on lateral sides. Elytra punctuation rather light and superficial, mainly in apical half. $\mathrm{TL}=3.7-4.1 \mathrm{~mm}$. A rare, relictual species of France, Italy and Greece quercicola

- Pronotum moderately convex and clearly bordered on lateral sides, at times such border paler than dorsal integuments (yellowish to brown). Elytra punctuation strong with deep and sparse points, this character evident on the whole elytral surface

12 Pronotum and elytra clearly crenulated on the whole lateral sides. Colour brown, pronotum lateral borders yellowish. $1^{\text {st }}$ and $2^{\text {nd }}$ sternites fitted with a pubescent, round impression. $\mathrm{TL}=4.3-4.9 \mathrm{~mm}$. Known from Sicily and Greece

marginatus

- Pronotum weakly crenulated and elytra nearly smooth on lateral sides. Colour dark greenish brown. $1^{\text {st }}$ and $2^{\text {nd }}$ sternites simple, without round impression. $\mathrm{TL}=$ 4.5-4.7 mm. All over Europe nigricornis

13 Body shape elongate, approx. cylindrical; head only slightly narrower than pronotum. Dorsal integuments moderately bright. $\mathrm{TL}=6.8-7.5 \mathrm{~mm}$. Southern Italy, Albania, Kerkyra island in Greece angelinii

- Body shape oval, head clearly narrower than pronotum. Dorsal integuments dull 14

14 Colour black with green reflections, rather dull. Antennae longer, antennal articles 6-9 similar to each other, triangular, rather large and wide; articles 4-5 also triangular but smaller, shorter and narrower (Fig. 11). Median process of last sternite $\widehat{\sigma}$ very short (Fig. 38). $\mathrm{TL}=5.5-6.8 \mathrm{~mm}$. Greece caelatus
- Colour deep black, dull. Antennae shorter, antennal articles triangular, more or less gradually widened from 4 to 9 . Median process of last sternite $\hat{\sigma}$ from very short to moderately developed.... 15

15 Pronotum lateral sides nearly smooth or slightly irregular, at most granulose. Median process of $\hat{\jmath}$ last sternite rudimentary to very short. TL $=4.7-6.4 \mathrm{~mm}$. East Bulgaria, north-east Greece, Turkey ....... reitteri

- Pronotum finely but clearly crenulated on lateral sides. Median process of $\hat{\sigma}$ last sternite rudimentary to moderately developed .

16 Size smaller: TL $=4.3-4.9 \mathrm{~mm}$. Antennal article 3 narrower than 4 (Fig. 12). Median process of last sternite $\hat{\sigma}$ embryonic or very short. Greece...cribrarius

- Size larger: TL $=$ 5.6-6.0 mm. Antennal article 3 nearly as wide as 4 (Fig. 14). Median process of last sternite $\widehat{o}$ moderately developed (Fig. 41). Bulgaria, northern Greece henrici

\section{Common description of the $A$. reitteri group}

The Aplocnemus reitteri group of species (points 14-16 of the above key), including caelatus, cribrari$u s$, henrici and reitteri, is very homogeneous. A short common description is here reported to avoid repetitions (but further specific characters will be supplied for each species):

$\hat{\jmath}$. Entirely deep black (only one species - caelatus - shows green reflections) including antennae and legs, but legs at times blackish or dark brown. Dorsal integuments very rough, more or less dull, strongly and densely punctuate. Body shape sub-oval: elytra, in their max. width (slightly behind the middle) wider than pronotum (in its max. width) which, in turn, is wider than head (including eyes). Pronotum convex, transverse; more or less rounded on lateral sides; posterior border longer than an-
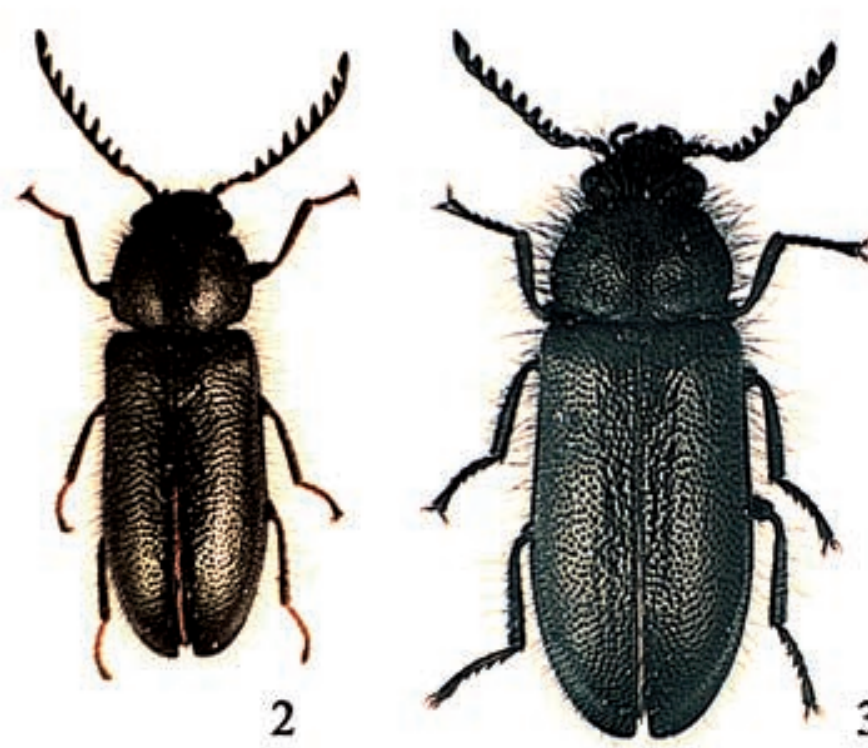

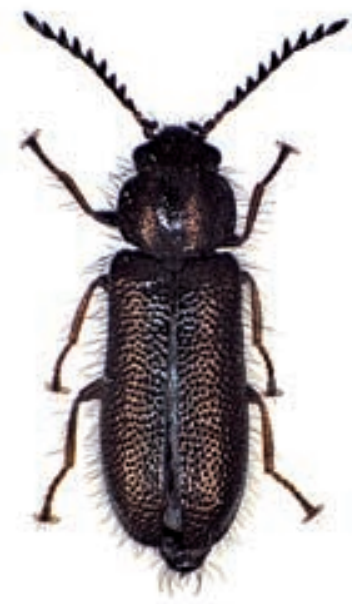

4

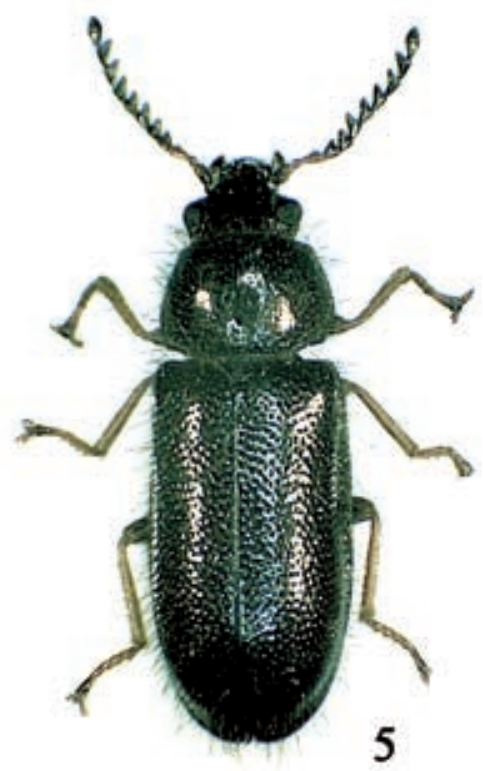

Figs. 2-5 - Habiti, $\widehat{\jmath}$.

2) A. basalis (Küster, 1849) (from Budva, MNE). 3) A. henrici n. sp (paratypus from Pissoderi, Florina, GR). 4) A. pertusus Kiesenwetter, 1859 (from Girne, CY). 5) A. rufipes Miller, 1862 (from Stavrodromi, Ahaia, GR). Scale: $1 \mathrm{~mm}$. 


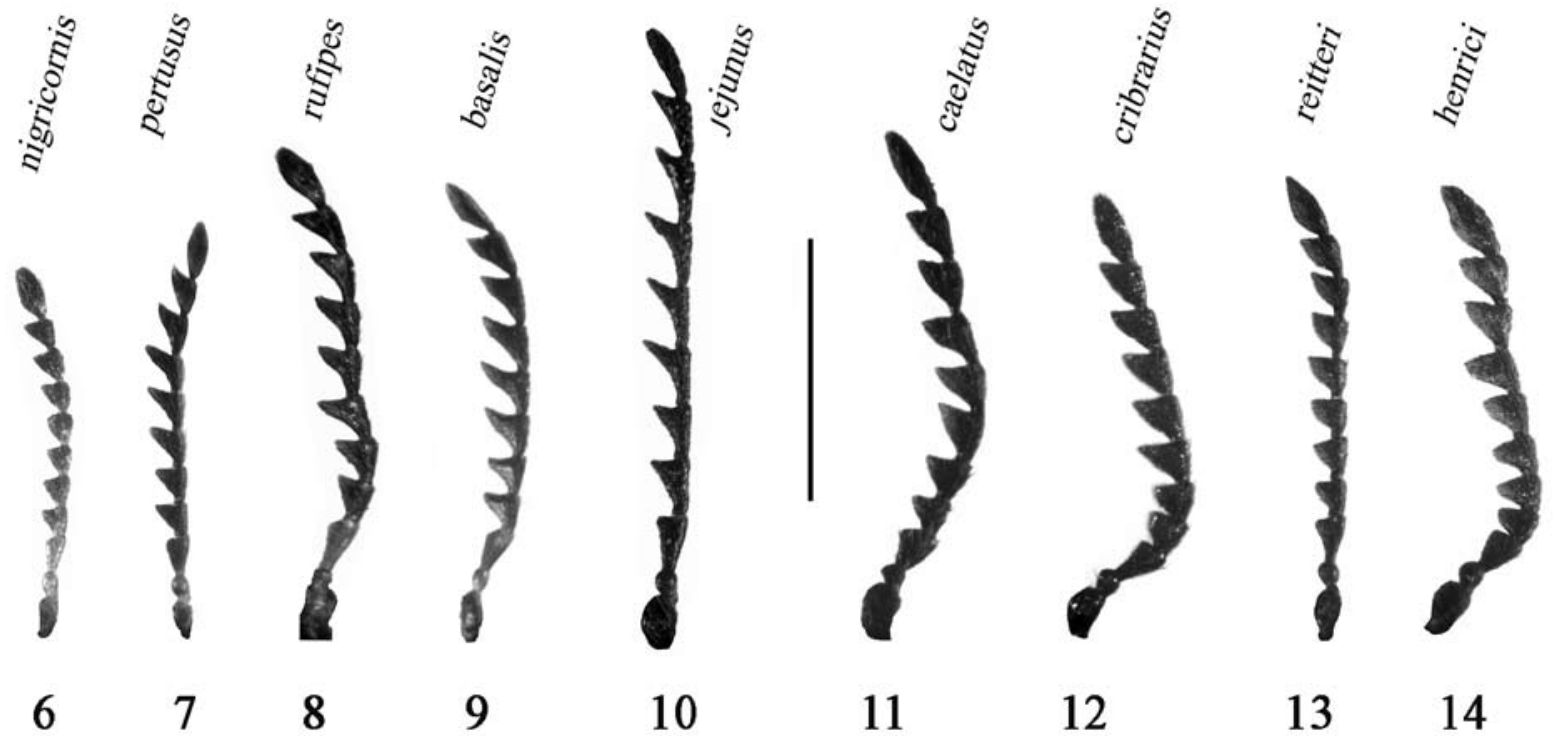

Figs. 6-14 - Right antennae, ふ઼े.

6) A. nigricornis (Fabricius, 1792) (from Aragnouet, Hautes Pyrenées, F). 7) A.pertusus Kiesenwetter, 1859 (from Girne, CY). 8) A. rufipes Miller, 1862 (from Stavrodromi, Ahaia, GR). 9) A. basalis (Küster, 1849) (from Budva, MNE). 10) A. jejunus Kiesenwetter, 1863 (from Castelfranco di Sopra, Arezzo, I). 11) A. caelatus (Brullé, 1832) (from Agios Nicolaos, Lakonia, GR). 12) A. cribrarius (Brullé, 1832) (from Kalanistra, Ahaia, GR). 13) A. reitteri Schilsky, 1894 (from Yenice, Çanakkale, TR). 14) A. henrici n. sp. (paratypus from Pissoderi, Florina, GR). Scale: $1 \mathrm{~mm}$.

terior; max. width slightly behind the middle; surface very densely punctate; distance between punctures smaller than their diameter; surface between punctures alutaceus, rather dull. Elytra as rough and dull as pronotum but more wrinkled and with punctures often merging into each other. Antennae thick, strongly serrate. Median process of last sternite usually underdeveloped or short (as, for example, in Fig. 38) but in one species - henrici - rather well developed (Fig. 41). Dorsal lever of median lobe often minutely denticulate on dorsal side.

. Closely resembling male: antennae bear the only sexual difference rather easily noticeable: thinner and less strongly serrate in females than in males. A difference can also be found (but sometimes hardly visible) in body shape which is slightly more convex in females, with elytral apex more regularly curved down (in males elytral apices are often shortly and slightly flattened).

\section{DISCUSSION OF THE SPECIES}

\section{A. (Diplambe) abietum Kiesenwetter, 1859}

(Figs. 47-52)

Haplocnemus abietum Kiesenwetter, 1859: 160, 171, loc. typ. Oros Parnitha (near Athens); Schilsky, 1894a: 60; Pic, 1937: 30; Peacock, 1987: 153; Mayor, 2007: 412; Liberti, 2009: 346.

= Haplocnemus latior Pic, 1908: 50 [syn. n.], loc. typ. Euboea; Pic, 1937: 36; Mayor, 2007: 411.

= Haplocnemus thessalicus Pic, 1908: 49 [syn. n.], loc. typ. Thessalia; Pic, 1937: 42; Mayor, 2007: 413.

= Haplocnemus atricornis Pic, 1921a: 3 [syn. n.], loc. typ. Kefallonia; Pic, 1937: 32; Mayor, 2007: 412.

The Kiesenwetter's types of $A$. abietum are probably lost. However only one Diplambe species is known of the
Balkan peninsula and 2 topotypes, $\hat{\partial} \hat{\partial}$, are available (see below under Material studied), well in agreement with the original description.

2 Syntypes $\hat{\partial} \hat{\jmath}$ of $H$. latior, both dissected by R. Constantin, are in Pic collection, at MNHNP, respectively labeled "Eubée, Bey Kyronurus [difficult to read]" hwA; "type" hwA; "latior Pic" hwA; "TYPE" prr. and "Eubée" hwA; "type" hwA. Both bear a further label "Syntype / Aplocnemus / latior / Pic 1908 / MNHN Paris, coll. Pic" prr., added by R. Constantin. They don't show any meaningful difference with the common and widespread $A$. (Diplambe) abietum.

2 Syntypes, $ㅇ+$, of $H$. thessalicus, originally pinned on the same pin, are in Pic collection, at MNHNP, labelled: "Thessalia" pr., "Diplambe sp. n." hwA, "type" hwA, "Type" prr. (in one of the two the labels have been transcripted by R. Constantin). Although $q \circ$ no meaningful difference with $A$.(D.) abietum has been detected.

2 Syntypes, 1 and 1 , of $H$. atricornis are in Pic collection, at MNHNP, labeled:

1 ठ̊: "Graecia, Kephallenia" pr.; "type" hwA; "atricornis Pic" hwA; "TYPE" prr.

1 q: "Graecia, Kephallenia" pr.; "type" hwA; "TYPE" prr.

Both specimens probably collected by Paganetti between 1899 and 1914. Here again, no meaningful difference with A.(D.) abietum has been detected.

Description - $\lambda$. Antennae evidently pectinate; articles 4-10 trasverse or very trasverse. Integuments blackishbrown, not very brigh; legs and antennae dark brown with tarsi more or less pale brown; mouthparts and palpi brownish; pubescence pale brown. Pronotum convex, max. width close to posterior border, rather lightly and sparsely 
punctured. Elytra very convex; lateral border double in basal half; sparsely punctured; surface between punctures moderately convex; elytral apices jointly rounded; apical angle rather well defined, right or slightly obtuse. Abdomen first and second visible sternites simple; fifth sternite straight or slightly convex on posterior side. Last sternite median process short (Fig. 51). Fallobase and parameres unconnected (not fused together) (Fig. 50).

․ Antennae serrate; elytra slighly more convex in apical half.

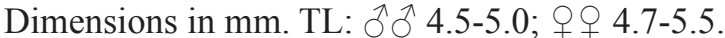

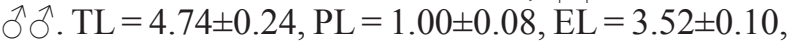

$\mathrm{PW}=1.62 \pm 0.05, \mathrm{EW}=1.92 \pm 0.10$.

우오. $\mathrm{TL}=5.16 \pm 0.37, \mathrm{PL}=1.10 \pm 0.11, \mathrm{EL}=3.78 \pm 0.25$, $\mathrm{PW}=1.74 \pm 0.13, \mathrm{EW}=2.10 \pm 0.11$.

Distribution and comments - $A$. (Diplambe) abietum is the only known representative, in the Balkans, of this rather large and widespread subgenus; it is common and widespread throughout the whole southern part of the Peninsula. It is probably present in Turkey as well, at least in the European provinces, however, being Diplambe a rather difficult group, future studies will better clarify its presence in this Country.

\section{Materials studied}

Romania

Baile Herculane (Deubel, ?, MSNM).

Makedonia

Struga (Schönhofer, 2006, SMNS).

Bulgaria

Katunci (Langourov, 2002, CMg; Migliaccio, 2002, $\mathrm{CMg}$ ); Mikrevo (Langourov, 2002, CMg; Lazarov, 2002, CMg); Petric (Migliaccio, 2004, CMg).

Greece

Lefkada prov.: Agios Nikitas (Angelini, 2005, CAn); Eglouvi (Angelini, 2005, CAn).

Kastoria prov.: Nestorio (Angelini, 2007, CAn).

Florina prov.: Simos Ioannidis near Florina (Liberti, 2005, $\mathrm{CLi})(\mathrm{F})$.

Grevenà prov.: Anoixis (Konviçka, 2009, CKn).

Serres prov.: Rodopoli (Angelini, 2007, CAn).

Evros prov.: Mega Derio (Angelini, 2007, CAn); Melia (Cocquempot, 2004, CLi)(F).

Ioannina prov.: Timfi, Farangi Vikou (Doguet, 1997, $\mathrm{CCo})^{*}$

Larissa prov.: Ossa (Egger, 1988, CEg; Saltini, 1998, CSl; Schülke, 1998, CPl; Ziegler, 2006, CZi); Spilià (Angelini, 2005, CAn).

Viotia prov.: Arahova (Liberti, 1997, CLi); Sarandavli (Angelini, 2005, CAn).

Atiki-Piréas prov.: Oros Parnitha: 20 (Liberti, 1997, CLi) (T)

Ahaïa prov.: Ano Diakoptò (Liberti, 1998, CLi); Aroania Ori (Rébl, 2010, CRe); Diakoftò (Angelini, 1998, CAn); Flamboura (Liberti, 1998, CLi); Kalavrita (Angelini, 1998, 1999, 2004, CAn; Cocquempot, 2004, CLi; Ziegler, 2010, CZi); Kalentzi (Angelini, 2004, CAn); Kastelli (Angelini, 2004, CAn); Lagovouni (Liberti, 1998, CLi); Mega Spileo (Ponel, 1996, CPn; Angelini, 1999, CAn); Stavrodromio (Angelini, 1999, CAn); Tripotama (Liberti, 1998, CLi).
Korinthia prov.: Bouzi (Angelini, 1999, CAn); Lafka (Angelini, 1999, CAn); Messinò (Ziegler, 2010, CZi); Mossia (Angelini, 2004, CAn); Nemea (Wittmer, 1971, CCo)*; Riza (Teunissen, 1998, CCo)*; Stilia (Saltini, 1994, CS1); Stimfalia (Angelini, 2004, CAn).

Ilia prov.: Katotari (Angelini, 2004, CAn); Olimbia (Angelini, 1999, CAn).

Arkadia prov.: Alonistena (Saltini, 2016, CSl); Dafni (Ziegler, 2010, CZi); Dimitsana (Doguet, 1995, CCo)*; Kandila (Angelini, 2004, CAn); Kardaras (Angelini, 2004, CAn); Panagitsa (Konviçka, 2009, CKn); Pigadakia (Angelini, 2004, CAn); Stavrodromio (Angelini, 1999, CAn); Tripoli (Angelini, 1999, CAn); Vitina (Ziegler, 2007, 2010, CZi).

Argolida prov.: Ahladokambos (Angelini, 2004, CAn); Mili (Angelini, 1999, CAn).

Lakonia prov.: Anavriti (Konviçka, 2009, CKn); Alepohori (Doguet, 1995, CCo)*; Gorani (Angelini, 2004, CAn); Kastania (Constantin, 1997, CCo)*; Toriza (Rébl, 2010, CRe); Vasiliki (Angelini, 2004, CAn).

\section{Aplocnemus (Aplocnemus) angelinii Liberti, 1995}

Russo, 1938: 115 (Haplocnemus sp.); Schatzmayr, 1943: 117 (Haplocnemus cylindricus).

Aplocnemus angelinii Liberti, 1995: 162, loc. typ. Policoro (Basilicata, Italy); Liberti \& Zinetti, 2009: 46.

For this species, description and drawings can be found in Liberti (1995: 192, Figs. 19-21).

Distribution and comments - Very close to $A$. (A.) cylindricus Kiesenwetter, 1863, of which it might be considered a subspecies, it lives in peninsular Italy and in south-west of the Balkan Peninsula: records are known from Albania, Kerkyra Island (Liberti, 1995) and Ahaïa.

A. (A.) angelinii, although similar to the reitteri group of species (see common description above), is easily recognized for pronotum less convex and approx. square shaped, as wide as elytral max. width so to give the body a cylindrical appearance, and for the space between punctures appearing brighter.

\section{Materials studied}

Albania

Berat $^{\circ}$ (Boldori, 1941, MSNM)(F)

Greece

Kerkyra prov.: Kerkira $^{\circ}$ (Champion, 1927, BMNH).

Ahaïa prov.: Metochi (Rébl, 2007, CRe)(F).

This species is also present in central and southern Italy: please refer to Liberti (1995) and Liberti \& Zinetti (2009) for the known localities in this Country.

\section{Aplocnemus (Aplocnemus) basalis (Küster, 1849)}

(Figs. 2, 9, 32-33)

Dasytes basalis Küster, 1849: 19, loc. typ. Trogir (Croatia); Pic, 1937: 32; Kaszab, 1955: 107; Majer, 1982: 430, 444, Figs. 4, 20; Peacock, 1987: 153; Mayor, 2007: 409; Liberti, 2009: 345.

= Haplocnemus basalis var. distinctipes Pic, 1908: 50, loc. typ. Kerkyra [synonymized by Majer, 1982: 430]. 
= Haplocnemus macedonicus Pic, 1922: 17, loc. typ. Mount Athos (Halkidiki) [syn. n.]; Pic, 1937: 37; Peacock, 1987: 155; Mayor, 2007: 411.

The types have been probably lost but the identification of this species, as proposed by Majer (1982), is here shared: it is common all over the Dalmatian coast and several topotypes are available.

A syntypus, $\hat{\sigma}$, of Aplocnemus basalis var. distinctipes Pic is at MNHNP in collection Pic, labelled: "Corfou" hw, "2 gardés Schilsky" hwA, "basalis, gardé par Schils 2" hwA, "basalis ou sp. près" hwA, "type" hwA, "basalis var. distinctipes Pic" hwA, "var. distinctipes" hwA, "TYPE" prr. (possibly added by Villiers), "Holotypus / Aplocnemus basalis / v. distinctipes Pic / vidit Liberti III.2007" prr. It shows no meaningful differences from the Trogir topo-typical population sample.

The typical series of Aplocnemus macedonicus Pic is made up by 12 syntypes, 11 (5 $\hat{\delta} \hat{\sigma}$ and $6+q)$ kept at MNHNP, 1 ( $\left.\jmath^{\Uparrow}\right)$ at MSNM (1 further $\hat{\jmath}$, MNHNP, has been set off the typical series because it bears a label " $\mathrm{H}$. pertusus" handwritten by Pic: evidently the Author had doubts on it).

The syntypes are labelled as follows:

1 † (MNHNP): "Athos, (Macedonien), Schatzmayr" pr.; "801" hw; "voir basalis" hwA; "type" hwA; "TYPE" prr. probably added by Villiers; "Syntypus, Aplocnemus, macedonicus Pic, vidit Liberti III.2007” prr.

1 O (MNHNP): "Athos, (Macedonien), Schatzmayr" pr.; "type" hwA; "macedonicus Pic" hwA; "TYPE" prr. probably added by Villiers; "Syntypus, Aplocnemus, macedonicus Pic, vidit Liberti III.2007” prr.

All others (MNHNP, MSNM) bear two labels: "Athos, (Macedonien), Schatzmayr" pr.; "Syntypus, Aplocnemus, macedonicus Pic, vidit Liberti III.2007” prr.

They show no meaningful differences from the Trogir topo-typical population.

Description - $\hat{\jmath}$. Antennae pectinate; articles 4 and 5 triangular, trasverse, inner side straight in 4, straight or feebly S-shaped in 5; 6-9 of increasing length; 7 and 8 clearly S-shaped on inner side (although in certain populations the inner side is nearly straight, as happens on Sveti Klement islet near Hvar). Integuments brown to dark brown, rather bright; antennae brown with basal articles variably paler (at least article 2 pale); femora brown, trochanters, tibiae and tarsi variably pale to brown (at least the first tarsal article yellowish); mouth parts and palpi brown. Pronotum convex, trasverse, max. width behind the middle, finely punctuate; punctures rather dense (a somewhat variable character), space between punctures wider than their diameter, bright, lateral sides granulose to finely crenulated. Elytra punctuation rather strong; space between punctures convex, bright; elytral apices separately rounded; apical angle undefined. Abdomen first and second visible sternites simple; fifth visible sternite moderately emarginated on posterior side; last sternite median process long. Basal undivided part of tegmen short (less than $1 / 4$ of total length).

q. As the male but antennae serrate and elytral apical half slightly widened.

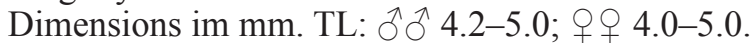

$\lambda$. $\mathrm{TL}=4.56 \pm 0.37, \mathrm{PL}=0.96 \pm 0.10, \mathrm{EL}=3.14 \pm 0.24$,
$\mathrm{PW}=1.38 \pm 0.13, \mathrm{EW}=1.66 \pm 0.06$.

우오. $\mathrm{TL}=4.68 \pm 0.47, \mathrm{PL}=0.96 \pm 0.06, \mathrm{EL}=3.32 \pm 0.31$, $\mathrm{PW}=1.46 \pm 0.13, \mathrm{EW}=1.72 \pm 0.15$.

Distribution and comments - This species lives in the southern part of the Balkans and is common in Dalmatia, where it has been collected, in spring, beating several kind of blossoming trees and shrubs (as, for example, $\mathrm{Pa}$ liurus sp.). It is probably present in the whole of Turkey as well, although apparently rare.

\section{Materials studied}

Croatia (localities listed from north to south)

Simuni, on Pag Is. (Liberti, 2004, CLi); Sukosan, near Zadar(Liberti, 2004, CLi); Dugopolje (Liberti, 2004, CLi); Donji Seget, near Trogir (Liberti, 2002, CLi)(T); Vinisce near Trogir (Liberti, 2004, CLi)(T); Split (Karaman, approx. 1900, CCo)*; Liuka, on Solta Is. (Liberti, 2002, CLi); Bol, on Brac Is. (Liberti, 2004, CLi); Drvenik, near Makarska (Liberti, 2004, CLi); Sveti Klement Is. near Hvar (Liberti, 2002, CLi); Vis town, on Vis Is. (Liberti, 2002, CLi); Slano (Herrmann, 1998, CPl); Ston (Poot, 1988, CCo)*; Mljet Is. (Gobanz, ?, MSNM); Pomena, on Mljet Is. (Boness, 1985, SMNS).

Montenegro

Bar (Liberti, 2008, CLi); Budva (Liberti, 2008, CLi); Kolasin (Constantin, 1998, CCo)*; Rastane (Liberti, 2008, CLi).

Greece

Halkidiki prov.: Sarti (Constantin, 1987, CCo)*. Agios Oros prov.: Athos (Schatzmayr, ?, MSNM).

Serres prov.: Therma (Bense, 1990, SMNS).

Kavala prov.: Nea Iraklitsa (Bense, 1990, SMNS).

Preveza prov.: Parga (Danielsson, 1997, ZMLU).

Ioannina prov.: Papigko on Timfi Mts. (Liberti, 2005, CLi).

Larissa prov.: Ossa (Ziegler, 2006, CZi).

Ahaïa prov.: Kalavrita (Angelini, 1998, CAn; Malkin, 1977, Co*); Kalogria (Angelini, 1999, CAn); Kato Vlassia (Malkin, 1977, CCo)*; Limanaki (Ziegler, 2010, CZi); Vouraikos Gorge (Ponel, 1996, CPn).

Korinthia prov.: Kaliani (Angelini, 1996, 1998, CAn); Kiato (Angelini, 1998, CAn); Oros Killini (Saltini, 1998, CS1); Perahora (Ziegler, 2010, CZi).

Ilia prov.: Olimbia (Frisch, 1987, ZMB).

Lakonia prov.: Taigetos (Pesarini, 1986, CLi).

Lesvos prov.: Olimpos, Lesvos Is. (Biström, 2005, MZF; Silfverberg, 2005, MZF).

Dodekanissa prov.: Kamiros, Rodos (Schmalfuss, 1992, SMNS).

Turkey

Bolu prov.: Aband near Bolü (Klapperich, 1965, CCo)*.

Zonguldak prov.: Ahmetusta Gecidi (Angelini, 2009, CAn)(F); Bartin (Angelini, 2009, CAn) (F); Karli (Angelini, 2009, CAn)(F).

Cankiri prov.: Ilgazdagi Gecidi (Angelini, 2009, CAn) (F).

Ordu prov:: Persambe (Angelini, 2009, CAn)(F).

Tokat prov.: Resadiye (Angelini, 2009, CAn, CLi).

Gümüshane prov.: Gümüshane (Angelini, 2009, CAn) (F).

Isparta prov.: Isparta (Coiffait, 1954, CCo)* 
Aplocnemus (Aplocnemus) caelatus (Brullé, 1832)

(Figs. 11, 36-38)

Dasytes caelatus Brullé, 1832: 150, pl. 37 fig. 2, loc. typ. Peloponnesus; Kiesenwetter, 1859: 174; Pic, 1937: 32; Peacock, 1987: 153 [Aplocnemus]; Mayor, 2007: 410.

= Haplocnemus pristocerus Kiesenwetter, 1859: 170, loc. typ. Nafplio, Athina [syn. n.]; Pic, 1937: 39; Mayor, 2007: 413 [Aplocnemus].

Types - Two syntypes are at MNHNP ("general collection"): one of them, ऽ, labelled "224" hw; "Dasytes / caelatus / Morée / M. Brullé" hw, this second label pinned on the box floor. The second syntype is in very bad conditions (only elytra and abdomen remaining) and is labelled "Dasytes caelatus Brullé" hw. The original description is rather accurate and make reference to the dark green overall colour which allows the (easy) recognition of this species.

The Kiesenwetter types of his Haplocnemus pristocerus have been lost but the description seems to be sufficient to allow an identification, so that little doubts remain on this synonymy. Kiesenwetter himself states that, probably, Brullé's Dasytes caelatus (and D. cribrarius, both unknown to him) could be placed "in the same systematic position" ("hierher zu beziehen") of his $H$. pristocerus.

Description - This species belonging to the "reitteri group", the above general description (under "Systematics") applies. Easily recognizable from all other Aplocnemus species for rough, dull appearance and green reflections.

Rather large, black with green reflections; legs and antennae black. Antennae (Fig. 11) rather elongate: article 3 triangular, elongate, slightly narrower than 4; 4-6 trasverse, 4 and 5 shorter and narrower than 6-9; 7-9 balanced and very slightly S-shaped on inner side. Pronotum lateral sides finely crenulated, mainly on basal half. Elytral apices separately rounded. Penultimate sternite straight or very feebly emarginated on rear border; last sternite median process very short (Fig. 38).

Dimensions in mm. TL: đ̂̃ 6.0-6.7; 우 5.1-6.2.

^ึ. $\mathrm{TL}=6.10 \pm 0.67, \mathrm{PL}=1.12 \pm 0.10, \mathrm{EL}=4.12 \pm$ $0.38, \mathrm{PW}=1.76 \pm 0.19, \mathrm{EW}=2.24 \pm 0.28$.

우우. $\mathrm{TL}=5.80 \pm 0.67, \mathrm{PL}=1.13 \pm 0.13, \mathrm{EL}=4.05$ $\pm 0.43, \mathrm{PW}=1.85 \pm 0.24, \mathrm{EW}=2.33 \pm 0.31$ ( 4 measures).

Distribution and comments - Apparently an endemics of southern continental Greece, where it is rather commonly found by grass sweeping.

\section{Materials studied}

Greece

Fthiotida prov.: Domokos (Krätschmer, 1980, SMNS).

Viotia prov.: Analipsi near Livadia (Liberti, 1998, CLi); Arahova (Doguet, 1996, CCo)*.

Atiki-Piréas prov.: Erithres (Liberti, 1998, CLi)(F).

Ahaïa prov.: Kalavrita (Teunissen, 1987, CCo*; Angelini, 1999, CAn).

Korinthia prov.: Agios Patapiou (Ziegler, 1996, SMNS); Bouzi (Angelini, 1999, CAn); Galatas (Köstlin, 1976, SMNS and CCo); Kaliani (Ziegler, 2010, CZi); Klitoria (Saltini, 2014, CSl)(F); Lafka (Angelini, 1999,
CAn); Oros Killini (Saltini, 1998, CSl); Riza (Teunissen, 1988, CCo)*; Sofikò (Angelini, 1999, CAn); Stilia (Saltini, 1994, CS1); Stimfalia (Angelini, 2004, CAn, CLi; Saltini, 2014, CS1); Zemenò (Ziegler, 2010, CZi).

Arkadia prov.: Agiorgitika (Doguet, 1995, CCo)*; Kardaras (Angelini, 2004, CAn); Levidi (Saltini, 2016, CS1); Panagitsa (Konviçka, 2009, CKn); Paradisia (Saltini, 2015 e 2016, CS1); Pigadakia (Angelini, 2004, CAn); Stavrodromio (Angelini, 1999, CAn, CLi); Vitina (Ziegler, 2010, CZi).

Argolida prov:: Ahladokambos (Angelini, 2004, CAn); Epidauros (Angelini, 1999, CAn); Mili (Angelini, 1999 and 2004, CAn); Mykenai (Malkin \& Riedel, 1981, CCo*; Frisch, 1987, ZMB); Skotini (Ziegler, 2007, CZi).

Messinia prov.: Kalamata (Köstlin, 1982, CCo)*.

Lakonia prov.: Agios Nikolaos (Angelini, 2004, CAn, CLi); Areopoli (Ziegler, 1996, SMNS); Arhontikò (Angelini, 2004, CAn); Arna (Angelini, 2004, CAn); Elafonissi (Schmalfuss, 1987, SMNS); Gerolimenas (Riedel, 1987, SMNS); Githio (Angelini, 2004, CAn); Gorani (Angelini, 2004, CAn); Kastania (Angelini, 2004, CAn); Polovitsa (Doguet, 1995, CCo*;Angelini, 2004, CAn); Melissa (Angelini, 2004, CAn); Melitini (Angelini, 2004, CAn); Mistras (Ziegler, 2011, CZi); Monemvassia (Rieger, 1987, SMNS; Constantin, 1997, CCo*); Skoura (Angelini, 2004, CAn); Taigetos (Sabella, 1984, CLi; Reichel, 1989, CCo*; Ziegler, 2007, CZi); Vasiliki (Angelini, 2004, CAn).

\section{Aplocnemus (Aplocnemus) corcyricus Miller, 1866}

Haplocnemus corcyricus Miller, 1866: 818, loc. typ. Kerkyra; Pic, 1937: 33; Peacock, 1987: 154 [Aplocnemus]; Liberti, 1995: 181; Mayor, 2007: 410; Liberti \& Zinetti, 2009: 47.

The lectotypus of this species has been recently defined (Liberti \& Zinetti 2009: 47): a female specimen believed to be part of the Miller's typical series. A full description, with drawings, of $A$. (A.) corcyricus can be found in Liberti (1995: 181, Figs. 10, 47, 48).

Distribution and comments - A trans-Ionian species, only known of Kerkyra Island in Greece and southern Italy, Sicily included. It is characterised by the clearly pectinate antennae, the size and the pitchy black colour of the whole body, legs and antennae included. The similar A. (A.) serratus, which can be found on Kerkyra as well, is smaller, with antennae strongly serrate (or feebly pectinate), body colour bluish-black and the basal antennal articles often more or less reddish.

\section{Materials studied}

Greece

Kerkyra prov.: Kerkyra (Hicker, ?, NHMB; Miller, ?, NHMW; Polatschek, ?, NHMW; Woerz, ?, CLi; Köstlin, 1985, CCO*); Gastouri (Winkler, ?, NHMB); Mount Deka (Woerz, ?, NHMB); Potamos (?, ?, NHMB).

This species is also present in southern Italy and in Sicily. The known localities in these Countries can be found in Liberti (1995) and in Liberti \& Zinetti (2009). 
Aplocnemus (Aplocnemus) cribrarius (Brullé, 1832)

(Figs. 12, 34, 35)

Dasytes cribrarius Brullé, 1832: 151, pl. 37 fig. 2, loc. typ. Peloponnesus (?); Kiesenwetter, 1859: 174; Heyden et al., 1906: 308 [Haplocnemus]; Winkler, 1925: 546; Pic, 1937: 33; Peacock, 1987: 154 [Aplocnemus]; Mayor, 2007: 410.

Types - The types of this species have not been found at MNHNP. Brullé described his Dasytes cribrarius on specimen(s) from the collection Laporte de Castelnau, part of which is now at the Melbourne Museum, but no types have been found there either (S. Hinkley, Melbourne Museum, private communication February $8^{\text {th }}, 2010$ ). For the time being, the types of this species should be considered lost. Also the typical locality might be doubtful because the Brullé species - when not collected by the "Expédition scientifique de la Morée" people - might come from elsewhere.

Brullé (1832) supplies a rather detailed description of Dasytes cribrarius, comparing it with the related, very similar D. caelatus: the descriptions are indeed similar and Kiesenwetter (1859: 174) even advanced the possible synonymy between them. On the other hand, in the catalogue of Heyden, Reitter \& Wise (1906: 308) the name cribrarius is listed as a variety of Aplocnemus cylindricus, as well as in the Winkler (1925: 546) catalogue where this conjecture is accepted (here listed as aberration).

But these Authors could not know that, in the Peloponnese, actually two similar species can be found: the above reported $A$. (A.) caelatus and the species here discussed and deemed to be the true $A$. (A.) cribriarius Brullé. This species rather well corresponds to Brullé's description, as detailed in Table 2.
The only disagreement between Brullé description and actual species is in the tarsi colour (which is a rather variable character in genus Aplocnemus) but the agreement of the other five characters can be considered reasonably good. After all, proposing this species as the true Dasytes cribrarius Brullé might be regarded as sufficiently safe, at least until the type(s) will, if ever, be found.

Description - This is the smallest species in the "reitteri group", whose common description is reported above, under "Systematics". Entirely black without reflections; legs and antennae black although, in one specimen, legs are dark brown to blackish. Antennae thick and rather long; articles 4-8 triangular and slightly trasverse, convex at inner side but article 8 very feebly S-shaped in some specimens; articles 4, 5 shorter and narrower than 6-9; article 3 triangular elongate but of variable size: either nearly as wide as, or clearly narrower than, 4. Pronotum lateral sides granulose. Elytral apical angle rather well defined, obtuse (but a variable character). Penultimate sternite straight to slightly emarginated on rear border; last sternite median process underdeveloped or very short.

Dimensions in mm. TL: ठึ $\widehat{\jmath}$ 4.3-4.9; 우우 4.2-4.9.

ふึ่. $\mathrm{TL}=4.60 \pm 0.29, \mathrm{PL}=0.94 \pm 0.10, \mathrm{EL}=3.18 \pm 0.27$, $\mathrm{PW}=1.66 \pm 0.49, \mathrm{EW}=1.72 \pm 0.13$.

우우. $\mathrm{TL}=5.06 \pm 0.75, \mathrm{PL}=1.00 \pm 0.14, \mathrm{EL}=3.52 \pm 0.52$, $\mathrm{PW}=1.60 \pm 0.23, \mathrm{EW}=2.00 \pm 0.31$.

Distribution and comments - An apparently rare species, only known from a few localities in southern and central Greece. Collected by grasssweeping.

Tab. 2 - Critical comparison between A. caelatus and A. cribrarius. The differences, between the two species, reported by Brullé (1832) are compared with the differences actually found (to support the interpretation of the name cribrarius here proposed).

\begin{tabular}{|c|c|c|c|}
\hline \multicolumn{2}{|c|}{$\begin{array}{l}\text { Brullé's differential diagnosis between } A \text { caelatus and } \\
\text { A. cribrarius }\end{array}$} & \multicolumn{2}{|c|}{ Actual comparison between the two species } \\
\hline A. caelatus & A. cribrarius & $\begin{array}{l}\text { A. cribrarius against } A . \\
\text { caelatus }\end{array}$ & Comment \\
\hline Punctuation deeper & $\begin{array}{l}\text { Punctuation smaller and } \\
\text { denser }\end{array}$ & $\begin{array}{l}\text { Punctuation similar, slightly } \\
\text { different on elytra (where, } \\
\text { in cribrarius, it might be } \\
\text { considered denser) }\end{array}$ & More or less in agreement \\
\hline $\begin{array}{l}\text { Pubescence not as dense, } \\
\text { which allows better sight of } \\
\text { surface punctuation }\end{array}$ & $\begin{array}{l}\text { Black pubescence much } \\
\text { more dense }\end{array}$ & $\begin{array}{l}\text { Pubescence only slightly } \\
\text { denser, on average, in } \\
\text { cribrarius }\end{array}$ & More or less in agreement \\
\hline $\begin{array}{l}\text { Brighter colour (“couleur } \\
\text { plus gaie") }\end{array}$ & $\begin{array}{l}\text { Body entirely black with an } \\
\text { hint of violet }\end{array}$ & $\begin{array}{l}\text { Good correspondence with } \\
\text { the differential diagnosis }\end{array}$ & Full agreement \\
\hline Antennae serrate & Antennae less serrate & $\begin{array}{l}\text { Good correspondence with } \\
\text { the differential diagnosis } \\
\text { (comparing same sexes) }\end{array}$ & Full agreement \\
\hline Pronotum transverse & $\begin{array}{l}\text { Pronotum balanced (not } \\
\text { wider than long) }\end{array}$ & $\begin{array}{l}\text { Pronotum actually less } \\
\text { transverse in cribrarius (but } \\
\text { still transverse) }\end{array}$ & Possible agreement \\
\hline Tarsi black & Tarsi reddish dark (rusty) & Tarsi black in both species & Disagreement \\
\hline
\end{tabular}




\section{Materials studied}

Greece

Fokida prov.: Amfissa (Saltini, 2014, CSl); Delphi (Frisch, 1987, ZMB).

Viotia prov.: Sarandavli (Angelini, 2005, CAn, CLi).

Ahaïa prov.: Diakoftò (Liberti, 1998, CLi); Kalanistra (Liberti, 1998, CLi \& CCo).

\section{Aplocnemus (Aplocnemus) henrici n. sp.}

(Figs. 3, 14, 39-41)

A species belonging to the reitteri group, deep black and rather large, living in Bulgaria and in northern Greece, whose typical locality is Mount Vitoscia, south of Sofia.

Dedicated to the friend Enrico Migliaccio, the name comes from "Henricus": an arbitrary latinization of his christian name (of german origin, probably derived from Heimrich).

Types - Holotype, ô (MSNM), labeled: "BG, Sofia, 1000-1250 m / Mt. Vitoscia vers. S / Strouma Valley, road / Bosnek - Chupetlovo / 16.VII.2005, Migliaccio".

Allotype, o (MSNM), labeled as the holotypus but with a different date: "5.VII.2001".

3 Paratypes $(1 \hat{O}, 1$ q $\mathrm{CLi} ; 1$ $\mathrm{CMg})$, same locality labels as the allotypus.

1 Paratype, ô (CMg): "BG, M.ti Rodopi occ. / (Velingrad), Lago Batak / 1140 m, 28.VI.2002 / leg. E. Migliaccio".

1 Paratype, ${ }^{\lambda}(\mathrm{CMg})$ : "Bulgaria merid. / Rila Mountains (Samokov) / Treshtenik dint., 1600 m / 25.VII.2001, Migliaccio".

1 Paratype, $\widehat{O}$ (CLi): "BG, Maleshevska Pl. / S Gorna

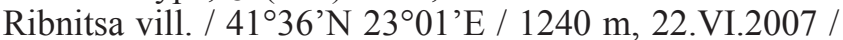
Ljubomirov".

1 Paratype, + (CLi): "GR, prov. Seres / Mt. Vrondous, Lailias / W. Ziegler, 22.VII.2009".

2 Paratypes, + + $(\mathrm{CLi}$ and $\mathrm{CZi}):$ "GR, prov. Florina / Pissoderi / W. Ziegler, 28.VII.2009".

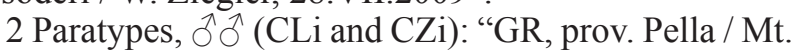
Voras / W. Ziegler, 29.VII.2009".

4 Paratypes, (1 $\sigma^{\lambda}: \mathrm{CLi} ; 2$ o, 1 9 : CZi): "GR, prov. Drama / Mt. Fulakro bis 1600 m / W. Ziegler, 20.VII.2009”.

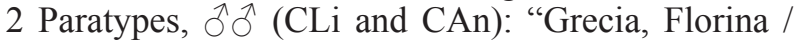
valico strada Pissoderi / Florina, 1400 m / 10.VI.2007, leg. Angelini".

1 Paratype, ô (CLi): "GR - 6; m 1450 / Pissoderi 2 Km E / 9.VI.2005, Liberti”.

2 Paratypes (1 $\hat{\jmath}, 1$, : CCo): "BULG. Rilagebirge / Maljowitzen $2600 \mathrm{~m} / 30$.VI.1989, leg. Zeuner".

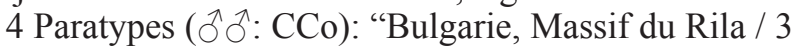
km N de Borouets / 17.VI.1996, G. Ledoux leg.".

1 Paratype (: CCo): "Greece, Florina, 1200 m / 20 km W Florina / pr. Pissoderi 2 km W/6.VIII.1987, R. Constantin"

All types bear a further label "Holotypus [or Allotypus or Paratypus where applicable] / Aplocnemus / henrici Liberti / (Lib. posuit, Gen. 2013)" prr.

Description - The above common description of the "reitteri group" species (please see under "Systematics") applies here.

Rather large, deep black without reflections; legs and antennae black but, in some specimens, legs may be dark brown. Antennae rather short; articles 4-9 transverse, convex at inner side; articles 4-6 of gradually increasing size; article 3 just elongate, width similar to 4 . Pronotum lateral sides finely granulose. Elytral apices separately rounded. Penultimate sternite straight on rear border. Last sternite median process well developed.

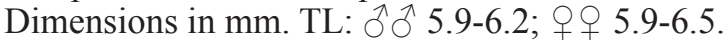

๙઼. $\mathrm{TL}=5.82 \pm 0.17, \mathrm{PL}=1.16 \pm 0.10, \mathrm{EL}=3.98 \pm 0.10$, $\mathrm{PW}=1.84 \pm 0.13, \mathrm{EW}=2.22 \pm 0.13$.

오. $\mathrm{TL}=6.12 \pm 0.26, \mathrm{PL}=1.22 \pm 0.05, \mathrm{EL}=4.34 \pm 0.19$, $\mathrm{PW}=1.92 \pm 0.10, \mathrm{EW}=2.36 \pm 0.13$.

Distribution and comments - $A$. (A.) henrici is known of Bulgaria and the north of Greece. The male specimen collected at Pissoderi by the writer was found by grass sweeping.

\section{Aplocnemus (Aplocnemus) integer Baudi, 1874}

Haplocnemus integer Baudi, 1874: 302, loc. typ. Pavia (Lombardy, I); Pic, 1937: 36; Kaszab, 1955: 106; Allenspach \& Wittmer, 1979: 100; Majer, 1982: 437 [Aplocnemus]; Peacock, 1987: 154; Liberti, 1995: 182; Kolibac et al., 2005: 153; Constantin, 2007: 162; Mayor, 2007: 411; Constantin \& Liberti, 2011: 52, 56, 134, 136, Fig. 99, pl. 19 fig. 76.

A syntype, $\hat{\partial}$, of this species is in collection Baudi, at MRSN. The specimen is in rather bad conditions, abdomen lacking. However it is well recognizable by the blue integuments colour and the elongated body shape. The previous interpretations of this species (Majer, 1982; Liberti, 1995) are here confirmed. Description, drawings and further collection localities can be found in Majer (1982), Liberti (1995: 182, Figs. 49, 50), Constantin (2007) and Constantin \& Liberti (2011).

Distribution and comments - An usually uncommon species (but, sometimes, found in numbers) living in central Europe, Corsica, the whole of Italy (not in Sicily and Sardinia) and the Balkans. Its presence in Turkey, witnessed only by one female specimen, should be confirmed.

\section{Materials studied}

Romania

Turda (Zoufal, ?, MSNM).

Greece

Imathia prov.: Kato Vermio (Schawaller, 1994, SMNS).

Thessaloniki prov.: Asprovalta (Wolsch, 2010, CWo).

Halkidiki prov.: Olimbiada (Riedel, 1990, SMNS); Stagira (Bergeal, 2001, CCo)*.

Serres prov.: Kerkini (Umlauf, 2014, CKo)(F).

Kavala prov.: Hrissoupoli (Bense, 1994, SMNS).

Xanthi prov.: Nestos river mouth (Bense, 1990, SMNS).

Turkey

Manisa prov:: Akcakertikbeli Gecidi near Demirci: 19 (Angelini, 2011, CLi)(F).

\section{Aplocnemus (Aplocnemus) jejunus Kiesenwetter, 1863} (Fig. 10)

Haplocnemus jejunus Kiesenwetter, 1863: 652, loc. typ. southern France; Pic, 1937: 35; Prota, 1966: 18, fig. III; Fiori, 1971: 56; Liberti, 1995: 167 [Aplocnemus]; Constantin, 2007: 161; Mayor, 2007: 411; Liberti, 2009: 369; Constantin \& Liberti, 2011: 50, 56, 133, 135, fig. 109, pl. 19 fig. 75.

Although the types are probably lost, there has been general agreement on the interpretation of this species. 


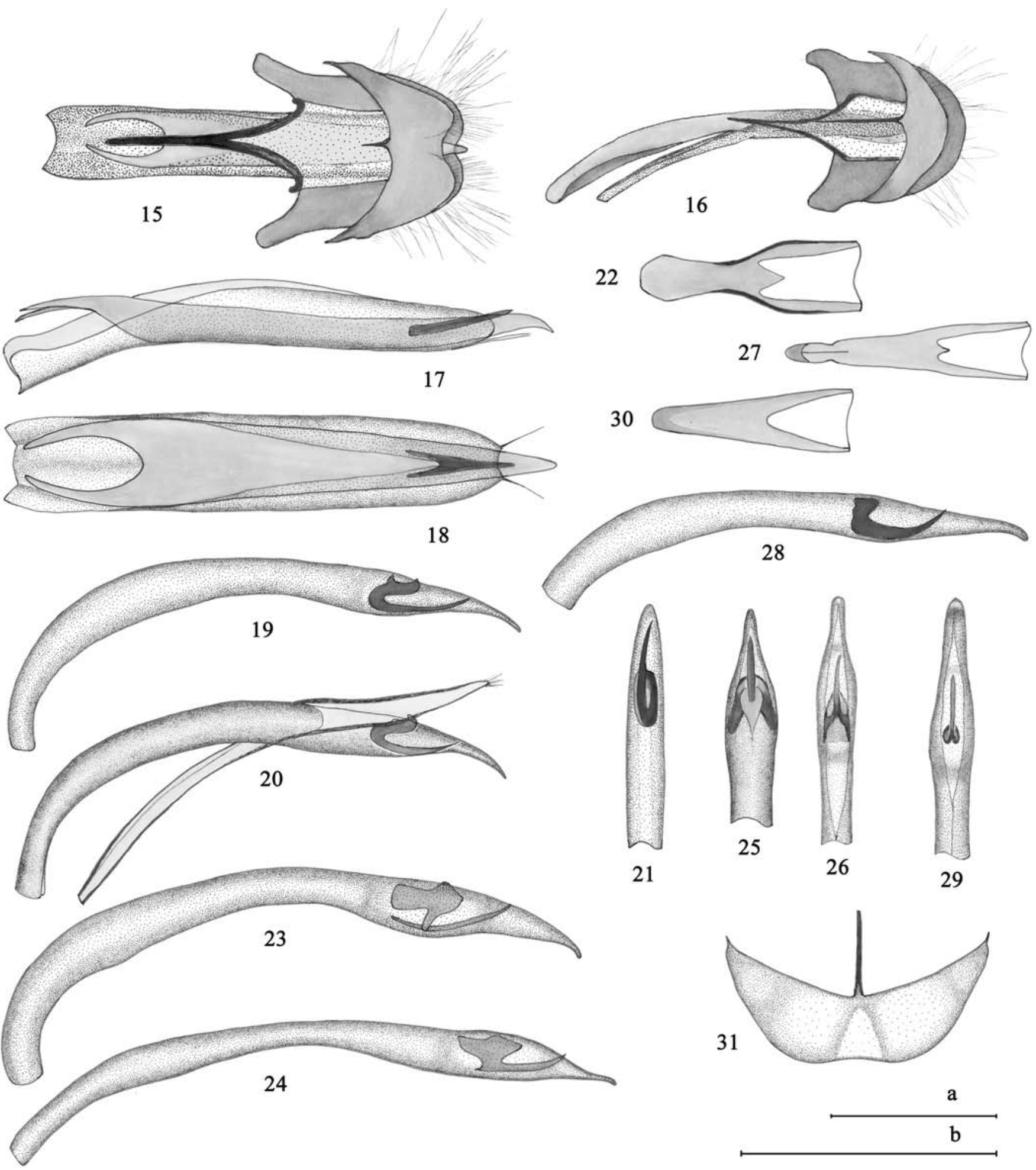

Figs. 15-31 - 15-16) Aedeagus, spicular fork and last ventrite (tergite and sternite) in sternal view, as they appear on dissection: all sternites and tergites - but the last ones - have been removed. 17) Aedeagus (median lobe with dorsal lever and tegmen), lateral view. 18) Aedeagus (median lobe with dorsal lever and tegmen), dorsal view. 20) aedeagus (median lobe with dorsal lever and tegmen), lateral view. 19, 23-24, 28) Median lobes, lateral view. 21, 25-26, 29) Median lobe apices, sternal view. 22, 27, 30) Basal half of tegmen. 31) Last sternite.

15) A. (Ischnopalpus) subcostatus Schilsky, 1894 from Tizi n'Test, 2000 m, Haut Atlas, Maroc. 16) A. rufipes Miller, 1862 from Anogia, Crete, GR. 17-18) A. (Ischnopalpus) subcostatus Schilsky, 1894 from Tizi n'Test, 2000 m, Haut Atlas, Maroc. 19-22) A. serratus (Brullé, 1832); 19) Karteri; 20-21) Vavouri near Tsamantas; 22) Agia Kiriaki all in Thesprotia, GR. 23-27) A. rufipes Miller, 1862; 23, 25) Lagavouni near Kalavrita, Ahaia GR; 24, 26) Anogia, Crete; 27) Hortiatis near Thessaloniki, GR. 28-31) A. pertusus Kiesenwetter, 1859; 28-30) Paliouri on Kassandra, Halkidiki, GR; 31) Silifke, Mersin, TR. Scales: $0.5 \mathrm{~mm}$. Scale a: Figs. 15, 16. Scale b: all others. 


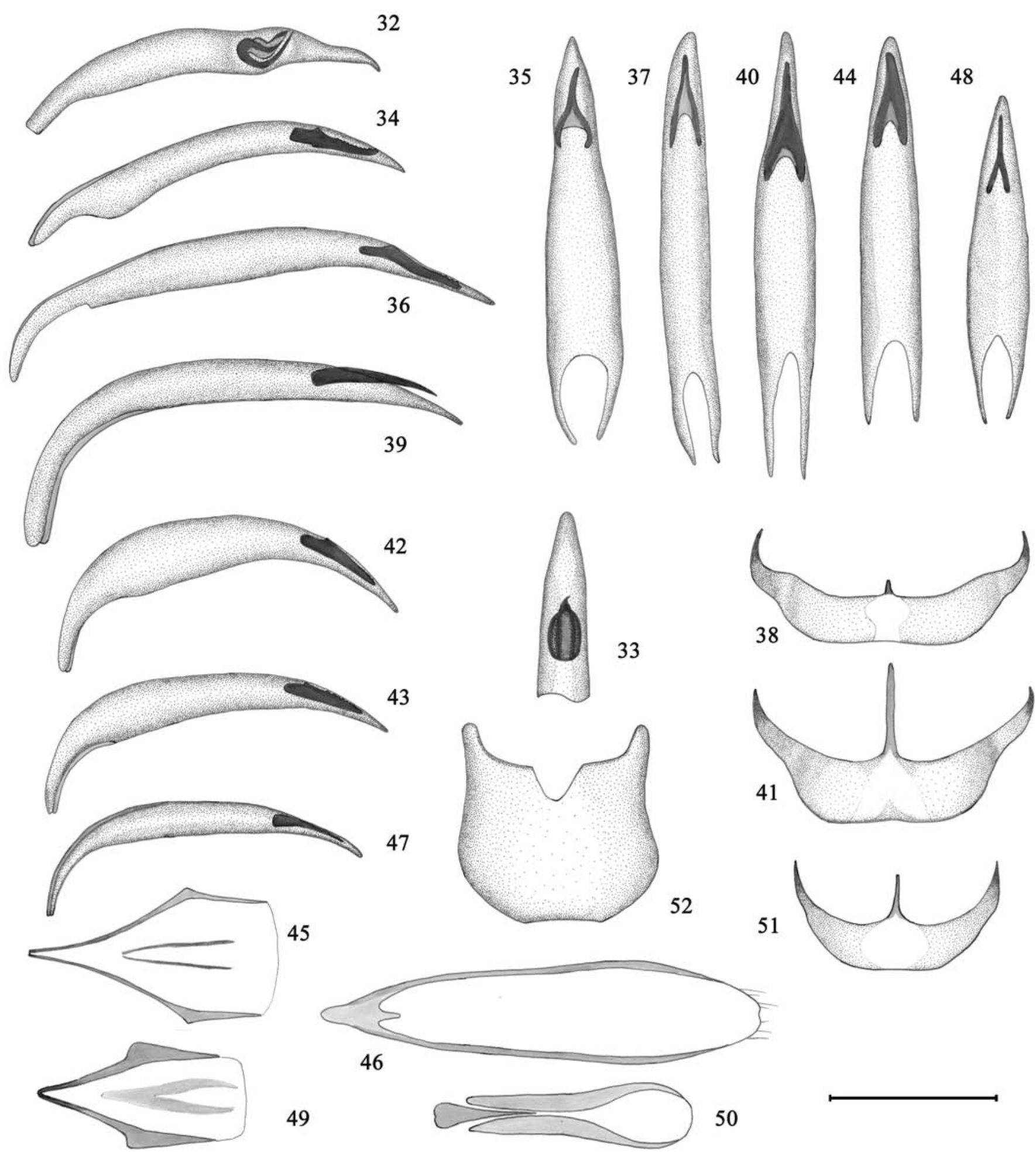

Figs. 32-52 - 32, 34, 36, 39, 42, 43, 47) Median lobes in lateral view. 33) Median lobe apex in sternal view. 35, 37, 40, 44, 48) Median lobes in sternal view. 46, 50) Tegmens. 45, 49) Spicular forks. 38, 41, 51) Last sternites. 52) Last tergite.

32-33) A. basalis (Küster, 1849); 32) Papigko on Timfi Mts., Ioannina, GR; 33) Vinisce near Trogir, HR). 34-35) A. cribriarius (Brullé, 1832) (both Kalanistra, Ahaia, GR). 36-38) A. caelatus (Brullé, 1832); 36) Stavrodromio, Arkadia, GR; 37-38) Agios Nikolaos, Lakonia, GR). 39-41) A. henrici n. sp. 39) Lake Batak near Velingrad, BG; 40) Bosnek-Chupetlovo near Mt. Vitoscia, BG; 41) Pissoderi, Florina, GR; all paratypes). 42-46) A. reitteri Schilsky, 1894. 42) Abant Gölü near Bolu, TR; 43-46) Dikili, Izmir, TR. 47-52) A. (Diplambe) abietum Kiesenwetter, 1859. 47, 49-52) Arahova, Ahaïa, GR; 48) Oros Parnitha, Atiki, GR, topotype. Scale $0.5 \mathrm{~mm}$ 
Description and drawings can be found in Liberti (1995: 167, Figs. 28-29) and Constantin (2007).

Distribution and comments - An uncommon to rare species, sometimes collected in winter under barks of trees or, late autumn and spring, by means of Malaise (or similar) traps. Present in southern France, Corsica, Sardinia, the whole of Italy, the Balkans and, probably, Turkey.

\section{Materials studied}

Slovenia

Branik [Reifenberg Castle] (Springer, 1942, MSNM).

Croatia

Momian, Istra (Schurmann, 1966, CLi).

Bulgaria

Balcik (Ziegler, 2015, CZi)F; Batovo (Ziegler, 2015, CZi)F; Sabla (Ziegler, 2015, CZi); Studen Kladenets (Chobanov, 2006, CMg).

Greece

Grevena prov.: Anixi (Berger, 2006, CBu)(F).

Turkey (European)

Tekirdag prov.: Yenice (Angelini, 2011, CLi)(F).

Further localities, for other Countries, are reported in Liberti (1995), Constantin (2007) and Liberti (2009).

\section{Aplocnemus(Aplocnemus) marginatus Rottenberg, 1871}

Haplocnemus marginatus Rottenberg, 1871:243, loc.typ. Catania(Sicily); Pic, 1937: 40 [synonym of A. rufomarginatus Perris, 1869]; Peacock, 1987: 156 [Aplocnemus; synonym of A. rufomarginatus]; Liberti, 1995: 184 [good species]; Mayor, 2007: 411; Liberti \& Zinetti, 2009: 49.

= Haplocnemus impressipennis Pic, 1921b: 5, loc. typ. Ficuzza (Palermo, Sicily) [synonymized by Liberti, 1995: 184].

No doubts on the identification of this species, as proposed by Liberti (1995), because it is well characterized and cannot be confused with any others in its typical locality (Sicily). Description and drawings can be found in Liberti (1995: 184, Figs. 2, 51-52).

Distribution and comments - A rare relictual, transIonian species living in Sicily and in the west of Greece.

\section{Materials studied}

Greece

Kefallonia prov.: Skala ${ }^{\circ 0}$ (Whitehead, 1996, CWh).

Etolia Akarnania prov.: Paleros ${ }^{\circ \circ}$ (Constantin, 2005, CCo).

Ahaïa prov.: Kalavrita ${ }^{\circ 0}$ (Angelini, 1999, CAn); Kalent$\mathrm{zi}^{\circ \circ}$ (Angelini, 2004, CAn)

Ilia prov.: Lalas (Schawaller, 2004, SMNS); Olimbia ${ }^{\circ 0}$ (Wittmer, 1971, CCo).

Messinia prov.: Mavrommati (Malkin, ?, CCo).

Several Sicilian localities for this species can be found in Liberti (1995) and Liberti \& Zinetti (2009).

\section{Aplocnemus nigricornis (Fabricius, 1792)}

(Fig. 6)

Lagria nigricornis Fabricius, 1792: 81, loc. typ. Sweden; Küster, 1849: 20 [Dasytes]; Kiesenwetter, 1859: 173 [Haplocnemus]; Kiesenwetter, 1863: 655; Mulsant \& Rey, 1868: 247; Schilsky, 1897: 48; Reitter, 1911: 289; Porta, 1929: 125; Pic, 1937: 37; Horion, 1953: 119; Kaszab, 1955:
105; Lohse, 1977: 180; Lohse, 1979: 73; Allenspach \& Wittmer, 1979: 97; Majer, 1982: 430, Figs. 6-7, 22, 31 [Aplocnemus]; Majer, 1987: 745, Figs. 169-203, 392; Peacock, 1987: 156; Liberti, 1995: 168; Constantin, 2005: 207; Alexander, 2005: 36; Kolibac et al., 2005: 152; Liberti \& Focarile, 2005: 31; Constantin, 2007: 160; Mayor, 2007: 411; Constantin \& Liberti, 2011: 54, 113, 135, Fig. 105, pl. 18 fig. 69; Booth, 2012: 69.

There is general agreement on the interpretation of this species which, in northern Europe, cannot be confused with any other. Description, drawings and a complete synonymic list are reported in Liberti (1995: 167, Figs. 3, 6, 30-31).

Distribution and comments - A widespread but usually uncommon species living in several northern European Countries, the whole of central and southern Europe, northwest Turkey (as below reported under "Materials studied").

\section{Materials studied}

Slovenia

Dutovlje (Schatzmayr, 1921, MSNM); Lipica Ergela (Schatzmayr, 1922, MSNM); Lokve Trnovski (Springer, 1917, MSNM; Alzona, ?, MSNG); Nova Gorica (Franciscolo, ?, CFr); Plesa (Schatzmayr, 1936, MSNM); Tronovski Godz (Franciscolo, 1994, CFr); Veliki Dol (Springer, 1916, MSNM); Vremscica (Springer, 1931, MSNM).

Croatia

Biokovo (?, ?, MSNM).

Serbia

Ruma (Schwieger, ?, MSNG).

Greece

Grevenà prov.: Deskati (Konvicka, 2016, CKn).

Rodopi prov.: Nea Santa (Angelini, 2007, CAn).

Evros prov.: Leptokaria (Bense, 1990, SMNS).

Ioannina prov.: Fourka (Rébl, 2008, CRe).

Evritania prov.: Karpenissi (Ponel, 1996, CPn).

Turkey

Kastamonu prov.: Daday (Assing, 2009, ZMB); Dom Kayatepe Gecidi (Wunderle, 2009, ZMB); Ilgaz Gecidi (Assing, 2009, ZMB).

Cankiri prov.: Eskipazar (Assing, 2010, ZMB).

This being a widespread european species, further localities in other countries can be found in Horion (1953), Allenspach \& Wittmer (1979), Liberti (1995) and Constantin (2007).

\section{Aplocnemus (Aplocnemus) pertusus Kiesenwetter, 1859} (Figs. 4, 7, 28-31)

Haplocnemus pertusus Kiesenwetter, 1859: 172, loc. typ. Nafplio (Greece); Schilsky, 1894a: 79; Schilsky, 1897: 34KK; Pic, 1937: 39; Peacock, 1987: 155 [Aplocnemus]; Liberti, 1988: 14; Schmalfuss, 1991: 103; Mayor, 2007: 411.

= Haplocnemus pertusus var. adaliensis Pic, 1908:50 [synonymized by Mayor, 2007: 411], loc. typ. Antalya (Turkey).

= Haplocnemus pertusus var. elongatior Pic, 1902: 32 [synonymized by Mayor, 2007: 411], loc. typ. "Anatolie" [sic].

= (?) Haplocnemus libanicus Pic, 1901: 9 [a doubtful synonymy: see below], loc. typ. Beirouth: Betmeri (Liban).

The Kiesenwetter's types should be considered lost, however this species is rather well characterized and the original description is sufficient for a reasonably reliable identification. 
At MNHNP, in collection Pic, box "Aplocnemus 5", one $\widehat{\partial}$ specimen of Aplocnemus pertusus var. elongatior Pic has been found, labeled: "Asie min. / Anatolie / CD [Charles Delagrange] 1888", "161", "61" and "v. elongatior Pic variation", without any indication of typical status.

In the same box it is also kept one Syntypus, + , of Aplocnemus pertusus var. adaliensis Pic, labeled "Adalia [now Antalya] / 1886 Korb." hw; "type" hwA, "TYPE" prr. "pertusus v. adaliensis Pic" hwA.

As Pic $(1902,1908)$ reports, both var. elongatior, described on male(s), and var. adaliensis, described on female(s), mainly differ from the typical form for the more or less pale (yellow to red) legs. But this character is very variable and nearly all specimens studied have legs, at least in part, yellowish to reddish.

In the same "Aplocnemus 5" box (collection Pic) 4 Syntypes of Aplocnemus libanicus Pic ( $2 \hat{\jmath} \widehat{\jmath}, 2$ 우) have been found. They are labeled:

1 q: "Betmeri [a suburb of Beirouth]" hwA; "type" hwA; "TYPE" prr.; "H. libanicus Pic" hwA.

1 ふै, 1 O : "Betmeri / Mai 99" hwA; "type" hwA; "TYPE" prr.; "H. libanicus Pic" hwA.

10ิ: "Sirie / Pic 1899" pr.; "Betmeri" hwA; "VI" hwA; Haploc. n. sp." hwA; "type" hwA; "H. libanicus Pic" hwA; "Syntypus / Aplocnemus / libanicus Pic / vidit Liberti 2008 " prr.

The last specimen has been dissected. The here suggested synonymy with $A$. pertusus should be taken with care: the median lobes show no differences but $A$. libanicus looks smaller and brighter. More material should be available to understand whether it could be considered a valid subspecies.

Description - 3 . Antennae pectinate; articles 4 and 5 similar, straight or convex at inner side, 5 slightly larger than 4, both narrower than 6-9; articles 6 and 7 transverse; 8 and 9 more or less balanced. Integuments brown rather bright; antennae brown with basal articles paler: light brown to yellowish; femora usually darker than tibiae; mouth parts brown; palpi paler than integuments; pubescence brown with whitish setae intermingled on elytral sides and apex. Pronotum not very convex, transverse, max. width approx. in the middle; punctuation rather strong but variable from sparse to very dense: brightness varies accordingly and so does the space between punctures; lateral sides granulose to feebly crenulated. Elytra punctuation stronger than on pronotum, rather dense, surface between punctures convex and bright (but, as for pronotum, a variable character); elytral apices mostly jointly rounded; apical angle right to acute. Abdomen first visible sternite with a dull, setose, small round area in the middle (not a true depression); second sternite simple; penultimate (fifth visible) moderately emarginated on posterior border; median process of last sternite rather long (Fig. 31). Tegmen basal part, undivided, not exceeding $1 / 4$ of total length.

. As the $\delta$ but antennae shorter, serrate; elytra moderately widened in apical half; first and fifth visible sternites simple. Pronotum brightness appearing more variable than in $\widehat{\partial} \widehat{\jmath}$.

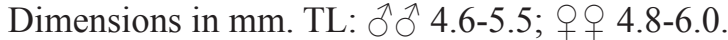

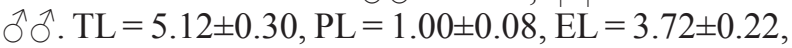
$\mathrm{PW}=1.54 \pm 0.13, \mathrm{EW}=1.86 \pm 0.13$.
오. $\mathrm{TL}=5.30 \pm 0.55, \mathrm{PL}=1.06 \pm 0.13, \mathrm{EL}=3.72 \pm 0.33$, $\mathrm{PW}=1.56 \pm 0.17, \mathrm{EW}=2.00 \pm 0.31$.

Distribution and comments - An east mediterranean species, found in Greece, Turkey and in the estern Mediterranean Island (Cyprus, Crete, Rhodos), rather common. Its presence on Thira (Kiklades: see below) suggests a good dispersal ability, taking into account the big volcanic eruption that, a few thousands years ago, wiped all forms of life out of the Island (Liberti 1988; Schmalfuss 1991).

\section{Materials studied}

Greece

Halkidiki prov.: Kriopigi (Köstlin, 1986, SMNS); Paliouri on Kassandra Peninsula (Berra, 1983, CLi).

Agios Oros prov.: Athos (Schatzmayr, ?, MSNM).

Serres prov.: Amfipoli (Berra, 1983, CLi).

Evros prov.: Melia (Cocquempot, 2004, CLi).

Atiki-Piréas prov.: Vouliagmeni (Hasselbarth, 1978, CCo)*.

Ahaïa prov.: Kalavrita (Malkin, 1977, CCo)*.

Korinthia prov.: Akrokorinthos (Ziegler, 1996, SMNS); Zemenò (Ziegler, 2010, CZi).

Lakonia prov.: Monemvassia (Rieger, 1987, SMNS).

Hania prov.: Hania (Saltini, 1992, CS1); Kalives (Gillerfors, 1993, ZMLU); Korunas (Kriti) (Gillerfors, 1993, ZMLU); Lakki (Gillerfors, 1993, ZMLU); Platanias (Gillerfors, 1993, ZMLU); Prasés (Migliaccio, 1996, CMg); Ramno (Ziegler, 2003, CZi); Vrises (Ziegler, 2011, CZi).

Rethimno prov.: Episcopi (Constantin, 1998, CCo)*; Kato Moni Preveli (Migliaccio, 1996, CMg); Panormos (Constantin, 1998, CCo)*; Perama (Ziegler, 2011, CZi); Plakias (Winkelmann, 1988, ZMB); Prinos (Fritzler, 1996, CCo)*; Rethimno (Köstlin, 1979, CCo)*.

Iraklio prov.: Agia Varvara (Constantin, 1993, CCo; Kopetz, 1998, CCo)*; Agios Ioannis (Migliaccio, 1996, CMg); Malia (Kopetz, 1998, CCo)*.

Lassithi prov.: Agios Nikolaos (Köstlin, 1975, CCo*; Ziegler, 2000, CZi); Kalo Horio (Ziegler, 2000, CZi); Kritsa (Ziegler, 2000, CZi); Lassithi (Köstlin, 1975, CCo)*; Prina (Ziegler, 2000, CZi); Vai (Constantin, 1993, CCo)*.

Lesvos prov.: Agios Paraskevi, Lesvos (Grimm, 1995, SMNS); Lesvos (Biström, 2009, MZF).

Kiklades prov.: Naxos Is. (Schatzmayr, 1909, MSNM); Profitis Ilias, Thira Is. (Baher, 1978, CSt)(F); Imerovigli, Thira Is. (Schlegel, 1979, CLi)(F).

Dodekanissa prov.: Embonas, Rodos (Grimm, 1996, SMNS): Kritinia, Rodos (Lange, 1990, SMNS); Profitis Ilias, Rodos (Lange, 1990, SMNS); Rodos (Schatzmayr, 1932, MSNM, Porta, 1942, MSNM; Franz, 1960 , CCo*); Trianda, Rodos (Schatzmayr, 1932, MSNM); Agios Konstantinos, Samos Is. (Malkin, 1979, CCo)*; Kokkari, Samos Is. (Burtscher, 1995, CCo)*; Pithagorio, Samos Is. (Malkin, 1979, CCo)*.

Turkey

Izmir prov.: Bergama (Klapperich, 1967, CCo)*; Güzelbahce (Diehr, 1993, ZMB).

Mugla prov.: Köycegiz (Ponel, 2005, CPn).

Antalya prov.: Beldibi (Kopetz, 1996, CCo)*; Demirtas (Kopetz, 1996, CCo)*; Dikmen (Ziegler, 2001, CZi, CLi); Antalya (Lubi, 1992, CEg; Ljubomirov, 2007, 
CMg); Calkaya (Ziegler, 2002, CZi)(F); Gündogmus (Ziegler, 2001, CCo*; Gillerfors, 2001, ZMLU)(F); Kas (Constantin, 2003, CCo)*; Side (Ziegler, 2001, $\mathrm{CZi})(\mathrm{F})$.

Mersin prov.: Silifke (Schurmann, 1967, CLi).

Hatay prov.: Harbiye (Saltini, 2000, CS1); Habibi Neccar near Hatay (Ljubomirov, 2007, CMg).

\section{Aplocnemus (Aplocnemus) quercicola Mulsant \& Rey, 1868}

Haplocnemus quercicola Mulsant \& Rey, 1868: 243, loc. typ. Beaujolais and Lyon area (France); Pic, 1937: 40; Constantin, 2007: 160 [Aplocnemus]; Mayor, 2007: 412; Liberti \& Zinetti, 2009: 51, Figs. 6,7; Constantin \& Liberti, 2011: 54, 114, 135, Fig. 102, pl. 18 Fig. 72.

= Haplocnemus brevissimus Pic, 1908: 50, note [syn. n.], loc. typ. Zakynthos and Olympia (Peloponnese); Pic, 1937: 32; Mayor, 2007: 410 [Aplocnemus].

= Haplocnemus brevissimus v. holtzi Pic, 1908: 50, note [synonymized by Mayor, 2007; a chromatic variety with darkened femora], loc. typ. Kambos, Messinia.

The types of $A$. (A.) quercicola have been described by Liberti \& Zinetti (2009: 51) and are in collection Rey, at the Centre de Conservation et d'Etude des Collections, Musée des Confluences, Lyon. Drawings and further collection localities (French and Italian) can be found in Constantin (2007), Liberti \& Zinetti (2009: 51, Figs. 6, 7) and Constantin \& Liberti (2011).

3 Syntypes, $q$ q , of Haplocnemus brevissimus Pic, 1908, have been found in collection Pic, at MNHNP. They are labeled:

"Morée" pr.; "type" hwA; "sp.?" hw, grey; "43” hw; "SYNTYPE" prr.;

"Olympia" hwA; "43" hw; "anomalie antennaire" hwA;

"Zante" hwA; "type" hwA; "brevissimus Pic" hwA; "TYPE" prr.

The 3 specimens bear a further label "Syntype / Aplocnemus / brevissimus / Pic 1908 / MNHN Paris, coll. Pic" prr., added by R. Constantin. Although small differences between french and greek populations samples can be detected, it seems wise to avoid establishing subspecies because of the limited number of specimens seen. On the other hand, given that Lyon and Athens are nearly 1700 $\mathrm{Km}$ apart, finding small differences between local populations should be expected.

The Holotype, $\{$, of Haplocnemus brevissimus var. holtzi Pic, 1908, is in collection Pic, at MNHNP. It is labeled: "Morea merid. / Kambos, Taygetos / VI.1901 Holtz" pr.; "rufipes var. / unique ?" hwA; "voir aussi / chalconatus" hwA; "type" hwA; "TYPE" prr.; "v. Holtzi Pic" hwA; "v. Holtzi Pic" hw on grey paper. The synonymy proposed by Mayor (2007) is here confirmed and justified.

Distribution and comments - A rare, relictual species present at least in Southern France, peninsular Italy, Greece and Crete (Liberti \& Zinetti, 2009: 51).

\section{Materials studied}

Greece

Larissa prov.: Ossa ${ }^{\circ}$ (Sama, 1987, CLi).
Messinia prov.: Agios Nikolaos near Kardamili ${ }^{\circ \circ}$ (Constantin, 2005, CCo).

Hania prov.: Vrises $^{\circ 0}$ (Gillerfors, 1993, ZMLU).

\section{Aplocnemus (Aplocnemus) reitteri Schilsky, 1894}

(Figs. 13, 42-46)

Haplocnemus (Holcopleura) reitteri Schilsky, 1894a: 59, loc. typ. Izmir (Turkey); Schilsky, 1894b: 234; Schilsky, 1897: 34BB; Reitter, 1907: 209; Pic, 1937: 40; Peacock, 1987: 156 [Aplocnemus (Holcopleura)]; Mayor, 2007: 413.

= Haplocnemus (Holcopleura) turcicus Schilsky, 1897: 30, 34CC [syn. n.], loc. typ. Burgas (Bulgaria), Edirne (TK), Turkey; Pic, 1937: 43; Peacock, 1987: 157 [Aplocnemus]; Mayor, 2007: 413 [Aplocnemus (Holcopleura)].

Types - Two Syntypes are kept at ZMB and can be identified as follows:

$1 \hat{\jmath}$, dissected by Majer, labelled: "Smyrna / Reitter" hw by Schilsky; "Reitteri / Schils." hw by Schilsky; a further red label "Holotypus", possibly added by Majer.

1 : "Smyrna" hw; "morio" hw; "Holcopleura / Reitteri / Schils." hw by Schilsky; "Aplocnemus / reitteri / Schilsky 1894 / K. Majer det. 1996” pr.

6 Syntypes of $A$. turcicus, 3 Jै $\delta$ and 3 우, are in collection Schilsky, at ZMB. They are labelled:

$1 \widehat{\delta}$ (dissected by K. Majer): "Apfelbeck / Burgas [BG]" pr.; "* turcicus / Schils." hw by Schilsky; "Haplocnemus / (Holcopleura) / turcicus / Schilsky 1897 / Lectotypus / Karel Majer design. 1996" prr., up.

$1 \delta$ (dissected by the writer) and $1+$ (dissected by K. Majer): "Adrianopel [now Edirne, TK] / Flach" hw by Schilsky; "Haplocnemus / (Holcopleura) / turcicus / Schilsky 1897 / Paralectotypus / Karel Majer design. 1996" prr., up.

1 ( ${ }^{\lambda}$ (dissected by K. Majer) and 2 오: "Turcia / Merkl" hw by Schilsky; "Haplocnemus / (Holcopleura) / turcicus / Schilsky 1897 / Paralectotypus / Karel Majer design. 1996" prr., up.

All of them have been fitted with a further label: "Syntypus / not a Lectotype / A. turcicus Schilsky / Liberti, jan. 2015 " prr.

The symbol "*" often found on Schilsky handwritten name labels means new species. Such symbol does not (in the writer's opinion) mean a holotype status for the relevant specimen. It is believed that such "*" mark was simply pinned, by Schilsky, on the first specimen of a new species row.

Describing this species, the Author reports 5 우 from "Turkey, Burgas and Adrianopel"; given the similarity between sexes it is easy to believe that Schilsky did not recognize the males. No doubt these are all syntypes, they all belong to the same species and there is no need to select a lectotype.

A. turcicus perfectly corresponds to $A$. reitteri, both for external and for aedeagical characters.

Description - Please refer to the above description under "Systematics". Rather variable in size, entirely black, legs and antennae included. Antennae rather short; articles 4-6 triangular, trasverse; 7-9 slightly trasverse to balanced; articles 4-6 gradually increasing in size; article 3 triangular, slightly narrower than 4 . Pronotum lateral sides 
finely crenulated, mainly in basal half. Elytral apices separately rounded although, at times, an obtuse angle may be perceived. Penultimate sternite straight on rear border; last sternite median process very short. The median lobe appears rather variable depending on populations as shown, as an example, in Figs. 42 and 43.

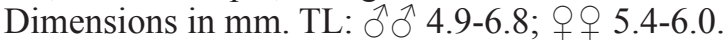

ふึ่. $\mathrm{TL}=5.50 \pm 0.78, \mathrm{PL}=1.08 \pm 0.22, \mathrm{EL}=3.78 \pm 0.52$, $\mathrm{PW}=1.70 \pm 0.22, \mathrm{EW}=2.16 \pm 0.24$.

오오. $\mathrm{TL}=5.62 \pm 0.27, \mathrm{PL}=1.14 \pm 0.06, \mathrm{EL}=4.02 \pm 0.15$, $\mathrm{PW}=1.78 \pm 0.10, \mathrm{EW}=2.26 \pm 0.10$.

Distribution and comments - A Turkish species, common in central and western Asiatic Turkey, also present in the European part of the Country and, marginally, in south-east Bulgaria. In Greece only on Lesvos. Can be found by grass sweeping.

\section{Materials studied}

Bulgaria

Ahtopol (Gren, 2012, CGz); Burgas (see syntypes of $A$ turcicus).

Greece

Lesvos prov.: Agios Paraskevi, Lesvos (Erhard, 1995, SMNS); Antissa, Lesvos (Grimm, 1995, SMNS); Eressos, Lesvos (Erhard, 1995, SMNS); Filia, Lesvos (Mus. Helsinki, 2007, MZF); Loutrà, Lesvos (Biström, 2009, MZF); Mantamados, Lesvos (Erhard, 1995, SMNS) Mitilini, Lesvos (Grimm, 1995, SMNS).

Turkey (European)

Canakkale prov.: Eceabat (Liberti, 2010, CLi)(F); Gelibolu (Liberti, 2010, CLi).

Turkey (Asiatic)

Bolu prov.: Abant Gölü near Bolu (Saltini, 1997, CLi).

Corum prov.: Bogazkale (Malkin, 1979, CCo)*.

Canakkale prov.: Ayvacik (Liberti, 2010, CLi); Yenice (Liberti, 2010, CLi, Angelini, 2011, CAn).

Balikesir prov.: Akbas (Liberti, 2010, CLi); Bandirma (Poot, 1989, CCo)*; Gölcük (Angelini, 2011, CAn); Gönen (Wittmer, 1970, CCo; Kanaar, 1989, CCo)*.

Bursa prov.: Kaynarca near Iznik (Wittmer, 1967, $\mathrm{CCo})^{*}$

Izmir prov.: Bergama (Klapperich, 1967, CCo; Malkin, 1981, CCo)*; Dikili (Liberti, 2010, CLi).

Manisa prov.: Akcakertigbeli Gecidi near Demirci (Liberti, 2010, CLi).

Aydin prov.: Kocarli (Ponel, 2005, CPn).

Denizli prov.: Çivril (Angelini, 2011, CAn).

Isparta prov.: Sarki Karagaç (Angelini, 2011, CAn).

\section{Aplocnemus (Aplocnemus) rufipes Miller, 1862}

(Figs. 5, 8, 16, 23-27)

Haplocnemus rufipes Miller, 1862: 345, loc. typ. Enos Oros, Kefallonia [the locality called by Miller "Monte Nero" being the ancient, Venetian name of Mount Enos on the island]; Schilsky, 1897: 51; Pic, 1937: 40; Peacock, 1987: 156 [Aplocnemus]; Mayor, 2007: 412.

= Haplocnemus kiesenwetteri Schilsky, 1897: 50 [syn. n.], loc. typ. Peloponnesus [the locality "Hagios Wlassis" reported by Schilsky, and visited by Brenske (the collector), might have been the village about $11 \mathrm{Km}$ south of Kalavrita, or the Monastry of Panagia Vlassias in Corinthia, $31 \mathrm{Km}$ east of Kalavrita, or else],
Atiki, Euboea; Pic, 1937: 36; Kaszab, 1955: 104; Majer, 1982: 441, Figs. 8, 23 [Aplocnemus]; Peacock 1987: 155; Mayor 2007: 411.

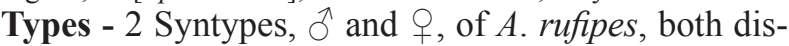
sected by Majer, are at the Wien Museum, labelled:

ऽ: "42" hw, light blue; "Miller / 864" hw; "rufipes [hw] / det. Schilsky [pr.]"; "rufipes" hw by Schilsky; "Haplocnemus / rufipes Miller 1862 / Lectotypus / K. Majer desig. 1997" prr., up.

O.: "Miller / 1862" hw; "rufipes [hw] / det. Schilsky [pr.]"; "rufipes" hw by Schilsky; "Haplocnemus / rufipes Miller 1862 / Lectotypus / K. Majer desig. 1997" prr., up.

The proposed synonymy with A. kiesenwetteri (already observed by K. Majer in 1997 and privately communicated to R. Constantin and to the writer) is based on the Schilsky description, also taking into account that, in the typical localities, this species is well characterized and cannot be confused with any other. Needless to say, this interpretation of $A$. kiesenwetteri is in agreement with Majer (1982) who supplied a short but meaningful description together with excellent drawings.

Description - $\hat{O}$. Antennae pectinate; article 4 triangular, balanced, straight or slighly convex at inner side; articles 5-9 of increasing length, S-shaped at inner side. Integuments colour green-brownish rather dark, bright; basal antennal articles, trochanters, tibiae and tarsi yellowish to reddish, femora more or less darkened; mouth parts partially yellowish, palpi yellowish with last article partly brown; pubescence brown with, here and there, paler setae (populations from Crete often are darker, with legs and antennae entirely brown). Pronotum transverse, convex, max. width well behind the middle; rather heavily punctuate, punctures small, sparse; surface between punctures much larger than their diameter, bright; lateral sides granulose. Elytra heavily (more than pronotum) but sparsely punctured; bright; elytral apices (more or less) jointly rounded; apical angle visible, right to obtuse. Abdomen with first and second visible sternites fitted with a small, round and setose depression in the middle; fifth visible sternite clearly emarginated on posterior border. Last sternite median process long. Basal undivided part of tegmen (fallobase plus parameres basal parts, joined together) long, approx. 1/3 of its total length.

\%. As the male but antenne serrate; elytra slightly widened in apical half; first, second and fifth sternites simple.

Dimensions in mm: TL.: $\widehat{\jmath}$ ô 4.8-5.9; 오 9 5.3-6.4.

${ }^{\lambda} \partial^{\lambda} . \mathrm{TL}=5.50 \pm 0.52, \mathrm{PL}=1.12 \pm 0.10, \mathrm{EL}=3.86 \pm 0.31$, $\mathrm{PW}=1.76 \pm 0.15, \mathrm{EW}=2.20 \pm 0.22$.

웅. $\mathrm{TL}=5.82 \pm 0.50, \mathrm{PL}=1.18 \pm 0.10, \mathrm{EL}=4.10 \pm 0.41$, $\mathrm{PW}=1.84 \pm 0.24, \mathrm{EW}=2.34 \pm 0.30$.

Distribution and comments - A southern Balkans species, rather common in southern Greece and recently found in central Turkey. It has been repeatedly collected by beating blossoming hawthorn shrubs.

Populations from the west of Crete are darker, with legs and antennae entirely dark brown, also showing tiny differences in median lobe and, more noticeable, in dorsal lever (compare Figs. 23, 24 and 25, 26).

\section{Materials studied \\ Greece \\ Kerkyra prov.: Kerkira (?, ?, MNH). \\ Lefkada prov.: Kalamitsi (Consatntin, 2005, CCo)*.}


Thessaloniki prov.: Hortiatis (Constantin, 2005, CCo*; Liberti, 2005, CLi); Taxiarhis (Bergeal, 2001, CCo)*; Thessaloniki (Schatzmayr, 1909, MSNM).

Halkidiki prov.: Holomon Oros, W of Arnea (Berra, 1983, CLi).

Agios Oros prov.: Athos (Schatzmayr, 1909, MSNM).

Trikala prov.: Afhin Kataras (Fabbri, 1995, MSNG); Meteora (Angelini, 2005, CAn).

Karditsa prov.: Lago Tavropoù (Konviçka, 2009, CKn); Neraida (Brustel, 2007, CBu).

Etolia Akarnania prov.: Paleros (Constantin, 2005, CCo)*; Potamoula (Angelini, 2005, CAn).

Evritania prov.: Karpenissi (Constantin, 2005, CCO)*.

Fokida prov.: Itea (Liberti, 1998, CLi).

Ahaïa prov.: Aroania Ori (Rébl, 2010, CRe); Kalavrita (Angelini, 1999, CAn; Ziegler, 2010, CZi); Kalentzi (Angelini, 2004, CAn); Kastelli (Angelini, 2004, CAn); Lagovouni (Liberti, 1998, CLi); Stavrodromio (Angelini, 1999, CAn).

Ilia prov.: Katotari (Angelini, 2004, CAn).

Arkadia prov.: Agios Petros (Hebauer, 1987, CCo)*; Dimitsana (Doguet, 1995, CCo)*; Dirrahi (Angelini, 2004, CAn); Kastanitsa (Rébl, 2010, CRe); Pigadakia (Angelini, 2004, CAn); Stavrodromio (Angelini, 1999, CAn); Tripoli (Angelini, 1999, CAn); Vitina (Angelini, 1999, CAn; Ziegler, 2010, CZi).

Argolida prov.: Ahladokambos (Angelini, 2004, CAn); Mili (Angelini, 1999, CAn).

Messinia prov.: Artemissia (Angelini, 2004, CAn); Exohori (Ziegler, 2011, CZi); Prosilio (Ziegler, 2011, CZi).

Lakonia prov.: Anavriti (Konviçka, 2009, CKn); Arna (Angelini, 2004, CAn); Githio (Frisch, 1989, ZMB); Gorani (Angelini, 2004, CAn); Kastania (Constantin, 1997, CCo)*; Taigetos (Köstlin, 1982, CCo; Doguet, 1995, CCo)*; Toriza (Rébl, 2010, CRe); Vasiliki (Angelini, 2004, CAn).

Hanià prov. (Kriti): Omalos (Egger, 2009, CEg).

Rethimno prov. (Kriti): Anoghia (Liberti, 2006, CLi; Schülke, 2006, ZMB); Rethimno (Köstlin, 1979, CCo) $(\mathrm{F})^{*}$.

Iraklio prov. (Kriti): Agia Varvara (Constantin, 1993, CCo)*.

Lassithi prov. (Kriti): Agios Nikolaos (?, 1976, ZMB); Armeni (Kopetz, 1998, CCo)*; Dikteon Antron (Malkin, 1977, CCo)*; Exo Mouliana 4 Km W (Constantin, 1993, CCo)*; Handras (Kopetz, 2000, CCo)*; Ierapetra (Köstlin, 1979, CCo)*; Kato Horio (Constantin, 1993, CCo)*; Kritsa(Constantin, 1993, CCo;Assing, 2012,ZMB)*; Stavrohori $3 \mathrm{Km}$ N (Kopetz, 2000, CCo)*; Vai (Constantin, 1993, CCo)*. Kiklades prov.: Vourkoti,Andros Is.(Liberti, 2007, CLi)(F). Turkey

Isparta prov.: Bagkonak (Angelini, 2011, CAn); Yukangökdere near Egirdir (Jansson, 2007, CCo)*.

Antalya prov.: Belpinar Gecidi (Angelini, 2011, CAn)(F). Konya prov.: Igdeören (Angelini, 2011, CAn, CLi).

\section{Aplocnemus (Aplocnemus) serratus (Brullé, 1832)}

(Figs. 19-22)

Dasytes serratus Brullé, 1832: 152, loc. typ. Peloponnesus; Pic, 1937: 41

[Haplocnemus]; Peacock, 1987: 156 [Aplocnemus]; Mayor, 2007: 412.

= Haplocnemus cribripennis Pic, 1921a: 3 [syn. n.], loc. typ.
Kefallonia; Pic, 1937: 33; Peacock, 1987: 154 [Aplocnemus]; Mayor, 2007: 410.

1 Syntype, $\hat{O}$, of $A$. serratus is at MNHNP, labelled "226" hw and "Dasytes serratus / Morée, M. Brullé", hwA, on the box floor.

2 Syntypes, both $ㅇ+$, of $A$. cribripennis are at $\mathrm{MN}-$ HNP, respectively labelled:

1 q: "Kephallenia, Paganetti" pr.; "type" hwA; “cribripennis Pic" hwA; "TYPE" prr.

1 : : "Kephallenia, Paganetti" pr.; "type" hwA.

Both bear a further red label "Syntype / Aplocnemus / cribripennis / Pic 1921 / MNHN Paris, coll. Pic" printed (but one partly hw.) added by R. Constantin (the 2 specimens were probably collected between 1899 and 1914). Although females, no doubt they belong to the same species called serratus by Brullé.

Description - $\hat{\sigma}$. Antennae strongly serrate or pectinate; articles 4 and 5 triangular, balanced or slightly transverse, their inner sides feebly convex; articles 6-9 gradually increasing length; 6 and 7 more or less transverse; 8 and 9 more or less balanced to elongate, feebly S-shaped or slightly convex on inner side. Integuments black, bright, with bluish reflections; antennae either entirely black or with basal articles yellow (north west Greece); legs black but, often, apical part of tibiae and tarsi paler; mouth parts and palpi dark brown to black; pubescence blackish to dark brown. Pronotum transverse, rather convex, max. width behind the middle; puncturation strong, sparse to rather dense (a variable character) but never very dense; space between punctures wider than their diameter, bright; lateral sides granulose to nearly smooth. Elytra punctuation stronger than on pronotum, spaces between punctures more or less convex, bright; elytral apices separately rounded; apical angle undefined. Abdomen first and second visible sternites simple; fifth visible sternite emarginated at rear border; central process of last sternite long. Basal undivided part of tegmen normal (approx. $1 / 4$ of total length).

9 . As the male but antennae serrate; elytral apical half moderately widened; elytral apical angle more or less visible, acute.

Dimensions in mm. TL: 令 4.0-5.1, 우 4.8-5.2.

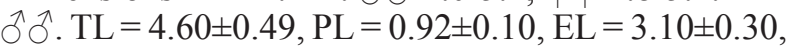
$\mathrm{PW}=1.36 \pm 0.13, \mathrm{EW}=1.66 \pm 0.13$.

오오. $\mathrm{TL}=5.00 \pm 0.18, \mathrm{PL}=0.98 \pm 0.05, \mathrm{EL}=3.38 \pm 0.10$, $\mathrm{PW}=1.50 \pm 0.08, \mathrm{EW}=1.88 \pm 0.13$.

Distribution and comments - The known distribution range of this species includes western and southern Greece and Dalmatia. Although often uncommon, at times it has been collected in numbers in certain places as, for example, the Igoumenitsa area (Thesprotia) by the writer, beating blossoming Phlomis sp. shrubs.

\section{Materials studied}

Croatia (localities listed from north to south)

Prezid Pan near Gracak (Liberti, 2005, CLi); Zedno (Konviçka, 2009, CKn); Mosor (?, 1911, MSNM); Sveti Jure near Makarska (Liberti, 2008, CLi).

Greece

Kerkyra prov.: Anaharavi (Göllner, 1996, ZMB); Kerkyra Island (Jünger, 1976, CCo*; Köstlin, 1985, SMNS and CCo; Whitehead, 1993, CLi). 
Lefkada prov.: Agios Nikitas (Angelini, 2005, CAn); Eglouvi (Angelini, 2005, CAn); Kalamitsi (Constantin, 2005, CCo)*.

Grevenà prov.: Deskati (Konvicka, 2016, CKn \& CLi).

Thesprotia prov.: Agia Kiriaki (Liberti, 2005, CLi); Ambelon (Liberti, 2005, CLi); Igoumenitsa (Doguet, 1997, CCo)*; Karteri (Constantin, 2005, CCo*; Liberti, 2005, CLi); Mavroneri (Constantin, 2005, CCo)*; Sagiada (Liberti, 2005, CLi); Vavouri near Tsamantas (Liberti, 2005, CLi).

Preveza prov.: Parga (Poot, 1998, CCo)*.

Etolia Akarnania prov.: Paleros (Constantin 2005, CCo)*; Sardinia (Poot, 1998, CCo)*.

Fthiotida prov.: Parnassos (Liberti, 2001, CLi).

Korintia prov. : Galatas (Köstlin, 1976, CCo)*.

Arkadia prov.: Paradisia (Saltini, 2015, CSl).

Messinia prov.: Exohori (Ziegler, 2011, CZi; Saltini, 2015, CSl); Kalamata (Köstlin, 1982, CCo)*; Kardamili (Constantin, 2005, CCo)*; Mavrommati (Malkin, 1979, CCo)*; Stavropigi (Frisch, 1987, ZMB).

Lakonia prov.: Areopoli (Doguet, 1995, CCo)*; Drialos (Constantin, 2005, CCo)*; Drimos (Constantin, 2005, CCo)*; Kelefa (Konviçka, 2009, CKn); Kokkala (Bergeal, 2000, CCo)*; Melitini (Angelini, 2004, CAn); Taigetos (Ziegler, 2007, CZi); Vahos (Doguet, 1995, CCo)*.

\section{Acknowledgements}

This paper is dedicated to the memory of my former friend Karel Majer, suddendly died on August 8, 2000, aged only 51 . Working on this text, many times I found traces of his presence and felt the sadness of his absence.

All keepers and Curators of the above listed Collections are gratefully aknowledged: this work has been possible thanks to their patience and their high minded attitude. I need to mention (in alphabetical order) at least: Fernando Angelini (who, as usual, made available huge amounts of materials), Marco Berra, Hervé Brustel, Robert Constantin, Ondrej Konvicka, Andreas Kopetz, Enrico Migliaccio, Isidor Plonski, Philippe Ponel, Lucio Saltini, Michele Tedeschi, Paul Whitehead, Wolfgang Ziegler.

A special thank is due to the Directions of several Institutions who have allowed and facilitated both retrieval and study of old types:

Bernd Jäger, Manfred Uhlig (previously) and Johannes Frisch of the Museum für Naturkunde, Humboldt Universität, Berlin, Germany;

Otto Merkl of the Hungarian Natural History Museum,

Budapest, Hungary;

Roberto Poggi of the Museo Civico di Storia Naturale "Giacomo Doria", Genova, Italy;

Hans Silfverberg of the Finnish Museum of Natural History, Helsinki, Finland;

Sharon Shute (previously) and Max Barclay of the British Museum, Natural History, London, England;

Harold Labrique, Joël Clary (previously) and Virgile Marengo (previously) of the Musée des Confluences, Centre de Conservation et d'Etude des Collections, Lyon, France;

Anna Alessandrello, Michela Mura, Maurizio Pavesi, Fabrizio Rigato and Michele Zilioli of the Museo di Storia Naturale di Milano, Italy;
Thierry Deuve and Azadeh Taghavian of the Museum National d'Histoire Naturelle, Paris, France;

Wolfgang Schawaller of the Museum für Naturkunde, Stuttgart, Germany;

Luca Picciau (previously) of the Museo Regionale di Scienze Naturali, Torino, Italy;

Heinrich Schönmann (previously) and Isidor Plonski of the Naturhistorisches Museum Wien, Austria.

Robert Constantin deserves a really special acknowledgement for his paramount role in preparing this paper: the rerieval and study of Pic types at MNHNP, the availability of many data from his important collection and the revision of the manuscript. He has also been a truly pleasant and patient "travel companion" in several entomological journeys to the Balkans.

I am very grateful to Gianluca Nardi who supplied a valuable and continuous bibliographical support and (together with an anonymous Revisor, to whom I am indebted too) made the hard work - spending a considerable amount of his time - of improving the text and minimize the mistakes.

\section{REFERENCES}

Agassiz L., 1846 - Nomenclatoris Zoologici Index Universalis, continens nomina systematica classium, ordinum, familiarum et generum animalium omnium, tam viventium quam fossilium, secundum ordinem alphabeticum unicum disposta, adjectis homonymiis plantarum, nec non variis adnotationibus et emendationibus. Jent et Gassmann, Soloduri.

Alexander K. N., 2005 - Aplocnemus nigricornis (Fabricius) (Melyridae) in Cornwall. The Coleopterist, 14 (1): 36.

Allenspach V. \& Wittmer W., 1979 - Insecta Helvetica Catalogus, herausgegeben von der Schweizerische entomologisches Gesellschaft. 4. Coleoptera. Cantharoidea, Cleroidea, Lymexylonoidea. Druck Fotorotar $A G$, Zürich. [Dasytidae: 96-113, compiled by R. Constantin].

Baudi a Selve F., 1874 - Europae et circummediterraneae Faunae Dasytidum et Melyridum specierum, quae Comes Dejean in suo Catalogo ed. 3a consignavit, ex ejusdem collectione in R. Taurinensi Musaeo asservata, cum auctorem hodiernae recepta denominatione, collatio. Berliner entomologische Zeitschrift, 15 [1873]: 89-316.

Bocakova M., Constantin R. \& Bocak L., 2011 - Molecular phylogenetics of the melyrid lineage (Coleoptera: Cleroidea). Cladistics, 27: $1-13$.

Booth R. G., 2012 - 51. Family Dasytidae Laporte, 1840. In: Checklist of the Beetles of the British Isles, $2^{\text {nd }}$ Edition. Duff A. G. (ed.). Pemberley Books Publishing, Iver: 69.

Brullé G. A., 1832 - IV.e Classe. Insectes. In: Expedition scientifique de Morée. Section des sciences physiques. Tome III, I ${ }^{\mathrm{e}}$ partie. Zoologie. II ${ }^{\mathrm{e}}$ Section. Des animaux ariculés. Brullé G. A. \& GuérinMenéville F. M. (eds.). F. L. Levreux, Paris et Strasbourg: 1-240.

Constantin R., 2005 - Révision des Aplocnemus Stephens ibériques (Coleoptera Cleroidea Dasytidae). Nouvelle Revue d'Entomologie (N. S.), 22 (3): 197-231.

Constantin R., 2007 - Révision des Aplocnemus de France avec description de trois nouvelles espèces. Observations taxonomiques et faunistiques sur les espèces françaises de Dasytidae et Acanthocnemidae (Coleoptera Cleroidea). Bulletin de la Société entomologique de France, 112 (2): 151-170.

Constantin R. \& Klausnitzer B., 1996 - 65 Familie: Melyridae. In: Die Larven der Käfer Mitteleuropas, 3. Band, Polyphaga Teil 2. Klausnitzer B. (ed.). Gustav Fisher Verlag, Jena: 188-203.

Constantin R. \& Liberti G., 2011 - Coléoptères Dasytidae de France. Musée des Confluences, Lyon.

Cooter J., 2006 - Glossary. In: A Coleopterist's Handbook (4 ${ }^{\text {th }}$ edition). Cooter J. \& Barclay M.V.L. (eds.). The Amateur Entomologist Society, Orpington, Kent, 11: 413-429.

Fabricius J. C., 1792 - Entomologiae Systematicae, Emendatae et Auctae secundum Classes, Ordines, Genera, Species, adjectis synony- 
mis, locis, descriptionibus, observationibus. Tom I. Pars II. Impensis Christ. Gottl. Proft, Hafniae.

Fiori G., 1971 - Contributi alla conoscenza morfologica ed etologica dei Coleotteri. IX. Psilothrix viridicoerulea (Geoffr.) (Melyridae Dasytinae). Studi Sassaresi. Sezione III: Annali della Facoltà di Agraria dell'Università di Sassari, 19: 1-70.

Heyden L., Reitter E. \& Weise J., 1906 - Catalogus coleopterorum Europae, Caucasi et Armeniae Rossicae. Editio secunda. Edmund Reitter, Paskau.

Horion A., 1953 - Faunistik der Mitteleuropäischen Käfer. Band 3. Malacodermata, Sternoxia. Entomologische Arbeiten aus dem Museum G. Frey, Sonderband, Eigenverlag, Munchen.

ICZN (International Commission on Zoological Nomenclature), 1999 International Code of Zoological Nomenclature, fourth edition. The International Trust for Zoological Nomenclature c/o The Natural History Museum, London.

Kaszab Z., 1955 - Különbözó Csápú Bogarak Diversicornia I. Lágytestú Bogarak Malacodermata (62 ábrával). Magyaroszág Allatvilága, VIII Kötet, Coleoptera III, 1. Füzet. Akademiai Kiadó, Budapest.

Kiesenwetter v. H., 1859 - Beitrag zur Käferfauna Grichenlands. Sechstes Stück: Malacodermata, Cleridae, Ptinidae, Anobiadae [sic]. Berliner entomologische Zeitschrift, 3: 158-192.

Kiesenwetter H., 1863 - Zweite Gruppe. Dasytina. In: Kiesenwetter H. Erste Abteilung, Coleoptera, vierter Band [appeared in parts, from 1856 to 1863]. In: Erichson W. F., Schaum H., Kraatz G. \& Kiesenwetter H., Naturgeschichte der Insecten Deutschlands. Nicolaischen Verlagsbuchhandlung, Berlin: 622-666.

Kolibac J., Majer K. \& Svihla V., 2005 - Cleroidea. Beetles of the superfamily Cleroidea in the Czech and Slovak Republics and neighbouring areas. Clarion Productions, Praha.

Küster H. C., 1849 - Die Käfer Europa's. Nach der Natur beschrieben. Mit Beiträgen mehrerer Entomologen. $19^{\circ}$ Heft. Bauer und Raspe, Nürnberg.

LeConte J. L., 1852 - Description of new species of Coleoptera from California. Annals of the Lyceum of Natural History of New York, 5: $125-216$.

Liberti G., 1988 - The fauna of the Aegean island of Thira. VIII. Dasytidae (Coleoptera). Giornale italiano di Entomologia, 4: 11-15.

Liberti G., 1995 - Revisione delle specie italiane del genere Aplocnemus Stephens (Coleoptera Melyridae Rhadalinae). Memorie della Società entomologica italiana, 73 (1994): 153-194.

Liberti G., 2005 - Improved solutions of two water soluble media for mounting beetle genitalia. The Coleopterist, 14 (1): 29-35.

Liberti G., 2009 -The Dasytidae (Coleoptera) of Sardinia. In: Research on the terrestrial Arthropods of Sardinia (Italy). Cerretti P., Mason F., Minelli A., Nardi G. \& Whitmore D. (eds.). Zootaxa, 2318: 339-385.

Liberti G. \& Focarile A., 2005 - I Dasytidae del Cantone Ticino (Coleoptera Cleroidea). Bollettino della Società Ticinese di Scienze naturali, 93: 19-39.

Liberti G., 2012 - A contribution to the knowledge of the european Trichoceble Thomson, 1859 (Coleoptera, Cleroidea, Dasytidae). Annali del Museo civico di Storia Naturale "G. Doria”, Genova, 104: 191-252.

Liberti G. \& Zinetti F., 2009 - Nota su alcuni Aplocnemus italiani nuovi o poco noti, con descrizione di Aplocnemus etruscus n. sp. (Coleoptera, Dasytidae). Bollettino della Società entomologica italiana, 141 (1): 45-53.

Lohse G. A., 1977 - Die mitteleuropäischen arten der Gattung Haplocnemus Steph. sowie synonymische bemerkungen zu andere Melyriden. Entomologishe Blätter für Biologie und Systematik der Käfer, Krefeld, 73: 175-183.

Lohse G. A., 1979 - 30. Familie: Melyridae (Dasytidae). In: Die Käfer Mitteleuropas. Band 6. Diversicornia. Freude H., Harde K. W. \& Lohse G. A. (eds.). Goecke \& Evers Verlag, Krefeld: 69-83.

Majer K., 1982 - Species of the genus Aplocnemus of Middle Europe (Col. Melyridae). Deutsche entomologische Zeitschrift (N. F.), 29: 421-445.

Majer K., 1985 - Supplementary notes to "Species of the genus Aplocnemus of Middle Europe" (Col. Melyridae). Deutsche entomologisches Zeitschrift (N. F.), 32 (1-3): 35-41.

Majer K., 1987 - Comparative morphology and proposed major taxon- omy of the family Melyridae (Insecta, Coleoptera). Polskie Pismo entomologiczne, 56: 719-859.

Mayor A., 2007 - Family Dasytidae Laporte, 1840. In: Catalogue of Palaearctic Coleoptera. Volume 4. Elateroidea - Derodontoidea Bostrichoidea - Lymexyloidea - Cleroidea - Cucujoidea. Löbl I. \& Smetana A. (eds.). Apollo Books, Stenstrup: 388-415.

Miller L., 1862 - Ergebnisse einer entomologischen Reise nach Cephalonia. Wiener Entomologische Monatschrift, 6 (11): 341-355.

Miller L., 1866 - Neue Käfer-Arten. Verhandlungen der kaiserlich-königlichen zoologish-botanischen Gesellshaft in Wien, 16: 817-820.

Mulsant E. \& Rey C., 1868 - Histoire naturelle des Coléoptères de France. Floricoles. Ed. Deyrolle, Paris.

Peacock E. R., 1987 - A review of the Rhadalinae (= Aplocneminae) (Coleoptera: Melyridae). Bulletin of the British Museum (Natural History), Entomology series, 56 (3): 129-170.

Pic M., 1896 - Diagnoses de Dasytides divers (in collection Pic). Miscellanea emtomologica, 4 (4): 47-48.

Pic M., 1901 - Notes diverses et diagnoses ( $2^{\text {eme }}$ article). L'Echange, Revue Linnéenne, 17 (194): 9-12.

Pic M., 1902 - Nouvelles espèces et variétés de Coléoptères paléarctiques. L'Echange, Revue Linnéenne, 18 (210): 31-33.

Pic M., 1908 - Descriptions ou diagnoses et notes diverses. L'Echange, Revue Linnéenne, 24 (283): 49-52.

Pic M., 1921a - Notes diverses, descriptions et diagnoses. L'Echange, Revue Linnéenne, 37 (403): 1-4.

Pic M., $1921 \mathrm{~b}$ - Notes diverses, descriptions et diagnoses. L'Echange, Revue Linnéenne, 37 (404): 5-8.

Pic M., 1922 - Notes diverses, descriptions et diagnoses. L'Echange, Revue Linnéenne, 38 (407): 17-19.

Pic M., 1937 - Pars 155: Dasytidae: Dasytinae. In: Coleopterorum Catalogus auspiicis et auxilio W. Junk. Schenkling S. (ed.). Dr. W. Junk Verlag für Naturwissenschaften, s'Gravenhage.

Porta A., 1929 - Fauna Coleopterorum Italica. Vol. III. Diversicornia. Stabilimento Tipografico Piacentino, Piacenza.

Prota R., 1966 - Contributi alla conoscenza dell'entomofauna della Quercia da sughero (Quercus suber L.). V. Osservazioni condotte in Sardegna su Oencyrtus kuwanoi (Howard) (Hymenoptera Encyrtidae) nuovo per la fauna italiana. Stazione sperimentale del Sughero, Tempio Pausania, Memoria nr. 17: 1-26.

Reitter E., 1907 - Coleopterologische Notizen. Wiener entomologische Zeitung, 26: 209-210.

Reitter E., 1911 - Fauna Germanica. III Band. Lutz' Verlag, Stuttgart.

Rottenberg A. v., 1871 - Beiträge zur Coleopteren Fauna von Sicilien. Berliner Entomologische Zeitschrift, 14 [1870]: 235-260.

Russo G., 1938 - VI Contributo alla conoscenza dei Coleotteri Scolitidae. Fleotribo: Phleotribus scarabaeoides (Bern.) Fauv. Parte seconda. Biografia, simbionti, danni e lotta. Bollettino del Laboratorio di Entomologia agraria, Portici, 2: 1-419.

Schatzmayr A., 1943 - Coleotteri raccolti dal Capitano L. Boldori in Albania. Atti della Società italiana di Scienze naturali e del Museo civico di Storia naturale di Milano, 82: 93-140.

Schilsky J., 1894a - Die Käfer Europa's. Nach der Natur beschrieben, von Dr. H.C. Küster und Dr. G. Kraatz. $30^{\circ}$ Heft. Verlag von Bauer und Raspe (Emil Küster), Nürnberg.

Schilsky J., 1894b - Beitrag zur Kenntniss der Dasytinen. Deutsche entomologische Zeitschrift, 1894 (II): 225-236.

Schilsky J., 1897 - Die Käfer Europa's. Nach der Natur beschrieben, von Dr. H.C. Küster und Dr. G. Kraatz. $34^{\circ}$ Heft. Verlag von Bauer und Raspe (Emil Küster), Nürnberg.

Schmalfuss H., 1991 - Santorin. Leben auf Schutt und Asche. Ein naturkundlicher Reisefürer. Verlag Josef Margraf, Weikerscheim.

Stephens J. F., 1830 - Illustrations of British Entomology; or, a Synopsis of indigenous Insects, containing their generic and specific Distinctions. Mandibulata vol. III. Publ. Baldwin and Cradock, London.

Suffrian C. W. L. E., 1843 - Entomologische Bemerkungen. Entomologische Zeitung, Stettin, 4: 330-337.

Thomson C. G., 1859 - Skandinaviens Coleoptera, synoptisk bearbetade, Volume 1. Berlingska Boktryckeriet, Lund.

Winkler A., 1925 - A, Caraboidea. B, Palpicornia, Staphilinoidea. C, Diversicornia. Pars 5, columns 497-624. In: Catalogus Coleopterorum regionis palaearcticae. Winkler A. (ed.). Albert Winkler, Wien. 